Review

\title{
Antibody-Mediated Rejection and Recurrent Primary Disease: Two Main Obstacles in Abdominal Kidney, Liver, and Pancreas Transplants
}

\author{
Tsukasa Nakamura ${ }^{1, *(D)}$ and Takayuki Shirouzu ${ }^{2}$ \\ 1 Department of Organ Transplantation and General Surgery, Kyoto Prefectural University of Medicine, \\ Kajii-cho 465, Kamigyo-ku, Kyoto 602-8566, Japan \\ 2 Molecular Diagnositcs Division, Wakunaga Pharmaceutical Co., Ltd., 13-4 Arakicho, shinjyuku-ku, \\ Tokyo 160-0007, Japan; shirouzu_t@wakunaga.co.jp \\ * Correspondence: tsukasa@koto.kpu-m.ac.jp; Tel.: +81-752-515-532
}

Citation: Nakamura, T.; Shirouzu, T. Antibody-Mediated Rejection and Recurrent Primary Disease: Two Main Obstacles in Abdominal Kidney, Liver, and Pancreas Transplants. J. Clin. Med. 2021, 10, 5417. https:// doi.org/10.3390/jcm10225417

Academic Editor:

Charat Thongprayoon

Received: 10 October 2021

Accepted: 18 November 2021

Published: 19 November 2021

Publisher's Note: MDPI stays neutral with regard to jurisdictional claims in published maps and institutional affiliations.

Copyright: (c) 2021 by the authors. Licensee MDPI, Basel, Switzerland. This article is an open access article distributed under the terms and conditions of the Creative Commons Attribution (CC BY) license (https:// creativecommons.org/licenses/by/ $4.0 /)$.

\begin{abstract}
The advances in acute phase care have firmly established the practice of organ transplantation in the last several decades. Then, the next issues that loom large in the field of transplantation include antibody-mediated rejection (ABMR) and recurrent primary disease. Acute ABMR is a daunting hurdle in the performance of organ transplantation. The recent progress in desensitization and preoperative monitoring of donor-specific antibodies enables us to increase positive outcomes. However, chronic active ABMR is one of the most significant problems we currently face. On the other hand, recurrent primary disease is problematic for many recipients. Notably, some recipients, unfortunately, lost their vital organs due to this recurrence. Although some progress has been achieved in these two areas, many other factors remain largely obscure. In this review, these two topics will be discussed in light of recent discoveries.
\end{abstract}

Keywords: antibody-mediated rejection; recurrent primary disease; renal transplantation; liver transplantation; pancreas transplantation

\section{Introduction}

From the late 20th century to the beginning of the 21st century, significant progress has been achieved in acute phase care for transplant patients. These advances firmly place organ transplantation into firmly established therapeutic procedures for organ failure patients. However, the better outcomes in the acute phase become, the more other issues are exposed. Firstly, donor specific anti-human leukocyte antigen (HLA) antibodies (DSA), resulting in chronic antibody-mediated rejection (ABMR), are recognized as major obstacles that we have yet to conquer. Organ transplantation is haunted by DSA unless we change graft sources or develop a new technology. Secondly, controlling the recurrence of the primary disease will continue to be a major issue in many diseases as long as we continue to use live organs and not machines.

The primary purpose of this review is to deepen the understanding of these two issues and to improve graft survival and patient survival after the acute phase of transplants.

\section{Methods}

We have written this review by focusing on two major issues: ABMR due to de novo DSA (dnDSA) and recurrence of primary disease. In preparing this review, Englishlanguage abstracts cited in PubMed were selected. Citations were chosen based on their relevance to each section. In Section 3, articles related with dnDSA, not preforming DSA, were selected. As recent dnDSA studies in kidney transplantation are summarized in a table, the most recent randomized trials or prospective cohort studies using representative drugs were selected as much as possible. Since the number of related studies is scarce in 
liver and pancreas transplants, we selected studies that included therapeutic approaches regardless of study design. In Section 4, we sought studies of a relatively large scale in order to show reliable recurrence data and also basic mechanisms as to why the primary disease recurs, if available.

\section{An Overview of Antibody-Mediated Rejection}

Rejection after organ transplantation is roughly divided into cell-mediated and antibody-related (humoral) immune mechanisms. Originally, T cell-mediated rejections (TCMRs) and ABMR against the ABO blood group were recognized as major barriers. In the 1970s, the introduction of cyclosporin, followed by tacrolimus, mycophenolate mofetil, anti-CD25 antibodies (Abs), and thymoglobulin, etc., dramatically reduced the incidence of severe acute TCMR. Furthermore, plasmapheresis and anti-CD20 Abs, which are recognized as desensitization, also brought better outcomes in $\mathrm{ABO}$ incompatible organ transplantation. Conversely, the issues regarding DSA are still disputable and seem not to be reasonably addressed. Therefore, discussions regarding ABMR and DSA are more frequently observed recently. This possibly reflects that the direction of researcher's interests is shifting to ABMR due to DSA, especially for chronic types as our interests shift to long-term outcomes [1]. Nevertheless, it is also true that close correlations between TCMR and the onset of DSA inducing ABMR are becoming apparent. Thus, the effects of TCMR are being reassessed from perspective of long-range consequences. Therefore, the discussion only between DSA and ABMR seems to be simplistic and could be enriched by a broader view, which adds TCMR. In this section, we will review chronic ABMR, TCMR, and related topics in kidney, liver, and pancreas transplants.

\subsection{Kidney Transplantation}

Kidney transplantation was the first successful organ transplantation and is the most frequently performed. Therefore, a large amount of knowledge about rejection has been gained, and this has improved outcomes so far in this field. However, ABMR due to DSA remains a major barrier to achieving a good prognosis in kidney transplants. In recent years, the impact of preformed DSA on ABMR has become smaller, but the impact of newly produced DSA (de novo DSA (dnDSA)) on ABMR is still significant. dnDSA could be detected at the stage of performing a biopsy by observing mild renal dysfunction or at the stage of protocol biopsy performed for an asymptomatic recipient. Patients who produced dnDSA have been reported to demonstrate worse graft survival rates than recipients without dnDSA [1].

Given the fact that the consequences of dnDSA production are significant, it is reasonable to believe that prevention and early detection are crucial for adequate management. Monitoring tests for anti-HLA Abs with an immobilized single allele of purified HLA are available for the detection of dnDSA [2]. Recently, it has been reported that the graft immunocomplex capture fluorescent analysis (ICFA) method using transplanted tissue pieces obtained by allograft biopsies is also effective for the early detection of DSA production [3]. Pathological diagnosis is widely used as a gold standard in diagnosing ABMR based on the Banff Classification, which was initially reported in 1993 with the aim of creating an internationally unified standard for kidney transplant pathology [4]. The Banff classification has been updated every two years and is a standard that reflects the current situation and helps clinicians in making diagnoses. In addition to introducing chronic active ABMR in 2001 [5], the concept of chronic TCMR was partially introduced in the 2005 Banff Classification update, and the 2017 Banff classification update recently introduced the features of chronic active TCMR. Chronic active TCMR can be considered as a major factor resulting in interstitial fibrosis and tubular atrophy (IFTA). IFTA is also associated with poor long-term outcomes. Moreover, considering inflammation in IFTA areas may supply better outcomes [6].

It must be admitted that the development of dnDSA is closely related to $\mathrm{T}$ cell activities. Activated B-lymphocytes linage cells start to produce dnDSA as a consequence of 
the interaction between B cells and CD4 T cells through direct, indirect, and semidirect pathways [2]. Thus, TCMR theoretically appears to have an important role in subsequent ABMR, although limited evidence exists. In a recent prospective study, the reported incidence of TCMR in the first year after transplant was around twice as high as in recipients who developed dnDSA compared with patients without dnDSA. The presence of dnDSA was associated with the severity of TCMR and subsequent graft loss. Furthermore, patients with dnDSA, accompanied by more severe tubulointerstitial inflammation, were more prone to recurrent TCMR [7]. Another study demonstrated that recipients with dnDSA accompanied by a prior history of TCMR showed inferior graft outcomes [8]. Taken together, these studies suggest that dnDSA-related ABMR is preceded by $\mathrm{T}$ cell involvement and also that TCMR affects graft outcomes through ABMR.

The risks of dnDSA development may vary according to an individual's immunological background. The rates of dnDSA development have been reported as being around $10 \%$ at 12 months after transplant under standard immunosuppressants [9,10]. However, recipients with high immunological risks (highly sensitized patients with high-titer of preformed DSA) are more susceptible to this particular development than those with low-risk, although preformed DSA became undetectable at 12 months after surgery with appropriate preparations [11]. In terms of immunosuppression, it is true, theoretically, that the levels of calcineurin inhibitors (CNI), mTOR inhibitors [12], antimetabolites [13], steroid, and several other monoclonal and polyclonal antibodies are related to the occurrence of dnDSA. Among them, CNI is one of the main immunosuppressants used to control dnDSA. High tacrolimus variability (instability) may well result in dnDSA production in pediatric recipients [14]. It can be admitted that this study has highlighted the importance of medication adherence. Furthermore, complete withdrawal from CNI by using mTOR inhibitors seems to favor dnDSA development [12,15]. Regarding steroid administration, this still plays an important role in controlling ABMR due to dnDSA [16]. On the other hand, there was a study that examined the effects of steroid withdrawal at 7 days posttransplant, and no negative effects on dnDSA were observed [17]. However, the latter study applied thymoglobulin induction for all recipients, which might alter immunological reactions. Therefore, the CNI and steroid-free strategies could involve immunological risks, although these approaches are attractive from the persepctive of medication side effects. It can be argued that the minimization of CNI by using mTOR inhibitors does prevent $\mathrm{CNI}$ toxicity. However, mTOR inhibitors without CNI or complete withdrawal from steroid administration pose a higher risk of DSA for recipients with standard induction therapy.

A variety of therapeutic approaches have been implemented, owing to the recent development of synthetic antibodies, in addition to orthodox therapeutic modalities. Several institutions applied steroid pulse, plasmapheresis, and intravenous immunoglobulin therapy (IVIG), combined with anti-CD 20 Abs administration for dnDSA mediated ABMR [18]. Other than these conventional therapies, several monoclonal Abs including eculizumab (anti-C5), tocilizumab, and clazakizumab (anti-interleukin 6) have recently been introduced in this field, although a proteasome inhibitor (bortezomib) failed to show therapeutic effects [19]. A pilot study to investigate the role of complement by using eculizumab showed a slight stabilization of renal function due to a terminal complement inhibitor, albeit with an underpowered design (treatment group $n=10$ ) [20]. Choi et al. reported $80 \%$ graft survival at 6-year post-introduction in tocilizumab-treated patients for whom IVIG and rituximab, with or without plasma exchange, did not succeed [21]. Several other investigations of tocilizumab and clazakizumab followed and showed a significant reduction in dnDSA [22] and a suppression of eGFR decline, respectively [23]. However, these studies indicate that a certain population of patients did not show the efficacy of these treatments. Thus, patient selection for dnDSA treatment would be another key issue in this field. On the other hand, belatacept-based immunosuppression clearly prevented the development of dnDSA, compared with an ordinal cyclosporin-based treatment regimen [24]. These results remind us of the importance of suppressing dnDSA development. Furthermore, in addition to the 
introduction of novel medications, it is also pivotal to seek optimal regimens with existing therapeutic modalities for dnDSA mediated ABMR.

\subsection{Liver Transplantation}

Despite the significant effects on graft survival of ABO blood type-related ABMR, the role of dnDSA in liver transplant remains largely unknown. There are many studies that demonstrate serum dnDSA (s-DSA) and graft outcomes. These studies demonstrated that the existence of s-DSA is not necessarily related with poor outcomes [25], which is contrary to the facts in kidney transplant. In other words, it is not wise to assess ABMR of liver allografts only by s-DSA. In fact, clinically, the Banff working group advocates diagnostic criteria that consist of (1) pathological findings, (2) positivity of DSA, (3) C4d positivity, and (4) excluding other causative factors [26]. These studies, regarding dnDSA, possibly include s-DSA positive but intra-graft DSA (g-DSA) negative cases (i.e., the circumstance where allografts are free from damages due to s-DSA). It is important to distinguish these cases clinically, although limited availability of DSA examination hinders routine investigations of g-DSA. In fact, our recent study showed that g-DSA was closely associated with graft rejection and could be a more reliable indicator for the graft outcomes [27]. On the other hand, other research studies suggest that DSA clearance by Kupffer cells [28], release of HLA from liver in soluble form [29], allografts size [30], and liver regenerative abilities prevent harming liver allografts [31]. Thus, believing the information regarding s-DSA only without questioning may misconstrue the truth of what happens in liver allografts.

With the minimization of immunosuppressants, it is often observed that liver transplant recipients also developed dnDSA in serum, with the tendency of this belonging to class II rather than class I [25,32]. In terms of the relation between dnDSA and TCMR, the prevalence of dnDSA was clearly higher in recipients who experienced TCMR, albeit without a correlation with frequency and severity [33]. With regard to the effects of dnDSA development, the correlation between dnDSA and more severe fibrosis was observed [34,35]. These studies also demonstrated that rejection signs existed more frequently in the dnDSA positive group. Interestingly, s-DSA positivity in subclinical TCMR tended to be associated with more severe inflammation and fibrosis, while s-DSA negative subclinical TCMR resulted in no histological rejection, supported by gene transcriptional evidence [36]. In a relatively large study, the relation between dnDSA and fibrosis can also be observed by looking at $61 \mathrm{dnDSA}$ positive patients among a total of 749 liver transplant recipients, albeit without pathological insights and HLA-C/DP information [37]. In this retrospective study, the most frequent target of HLA was the DQ locus $(85 \%$, 52 out of 61 patients). Cyclosporin usage rather than tacrolimus and low CNI levels (tacrolimus $<3 \mathrm{ng} / \mathrm{mL}$, cyclosporin $<75 \mathrm{ng} / \mathrm{mL}$ in the first year) were detected as risk factors of developing dnDSA. On the other hand, high model for end-stage liver disease (MELD) scores and advanced recipient age $(>60)$ functioned as protective factors. These findings appear to be consistent with immunological theories, i.e., deteriorating or elderly patients may exhibit milder immunological reactions.

Given the fact that the existence of dnDSA does not necessarily indicate the onset of ABMR, it is still unclear whether we should make interventions against the status of positive dnDSA. Conversely, it is better to seek remedies if ABMR is confirmed based on the Banff criteria. To address ABMR due to dnDSA, several therapeutic strategies have been applied so far. Simple reinforcement of immunosuppressants appears to be the first choice. Several cases showed a reduction in s-DSA MFI [32]. In addition, several institutions seem to apply other therapies for ABMR just as in renal transplant: anti-CD 20 Abs, IVIG, and plasmapheresis [38,39]. However, it seems to be rare to reverse the severe fibrotic changes after the onset of chronic ABMR. Thus, at present, it is of vital importance to prevent the development of dnDSA and subsequent ABMR. 


\subsection{Pancreas Transplantation}

Due to improvements in surgical techniques and immunosuppression protocols, the graft survival of pancreas transplant has greatly improved. Similarly to other organs, with the pancreas, it is true that our attention has been shifting from these acute issues to ABMR. However, the association between dnDSA and graft outcomes is not well understood. Several studies have demonstrated the negative impact of ABMR on pancreas graft survival. However, many of these studies were limited by retrospective styles, small sample size, or lack of histological assessment. Among them, de Kort et al. initially investigated 27 pancreas transplant patients according to their s-DSA and biopsy findings. Graft survival largely depended on s-DSA positivity accompanied by complement activation (C4d positivity) [40]. Furthermore, they revealed that ABMR played a significant role in early graft loss $<1$ year after transplant, especially in the setting of thrombotic cases [41]. Without histological assessment, a larger study consisting of 167 pancreas transplant recipients showed that about $15 \%$ (26/167) recipients developed s-DSA during a nine-year follow-up and resulted in significantly inferior outcomes: graft survival dropped around $30 \%$ and $20 \%$ from recipients without anti HLA Abs and DSA, respectively [42].

Regarding the class of DSA, a large part of dnDSA belonged to class II [43], especially DQ [44]. These results are also consistent with findings of kidney and liver transplants. Considering the recent developments in HLA matching, a more sophisticated approach should also become possible in the field of pancreas transplant. This approach demonstrated that the development of dnDSA after pancreas transplant was associated with the number of predicted indirectly recognizable HLA epitopes (PIRCHE) II [45]. Practically, it seems to be difficult to consider all information regarding HLA prior to deceased organ transplant. Nonetheless, it would be plausible to cater tailored immunosuppression based on their immunological status, provided that details of donors' HLA information are supplied.

Although there is no research focusing on the optimal treatment for ABMR in pancreas transplant, the ABMR of pancreas grafts seems also to be managed by additional anti-humoral therapies with reinforcement of standard immunosuppressants $[40,42,43]$. However, it is controversial to initiate preemptive treatments for dnDSA positive cases without ABMR signs. Uva et al. added Belatacept to the maintenance of immunosuppressants for selected patients, although they denied universal preemptive interventions [46].

Overall, ABMR in pancreas transplant remains relatively unclear compared to other fields. Given the fact that many pancreas transplants have been conducted together with kidney transplants, research on ABMR in pancreas transplant would progress with the knowledge of kidney transplants. Indeed, there are criteria for ABMR of pancreas grafts [47]. Due to the hesitancy regarding pancreas graft biopsies, it must be admitted that an accurate assessment of rejection in pancreas graft is limited on several occasions. In addition to pancreas biopsies, there is a different approach: Duodenal graft biopsies have been taken [48]. This procedure may additionally shed light on pancreas graft ABMR according to intestinal transplantation and could improve outcomes. Limited knowledge of pancreas ABMR demands large prospective cohorts in the future.

Recent studies regarding chronic ABMR due to dnDSA in each field are summarized in Table 1. 
Table 1. Summary of recent studies in chronic ABMR due to dnDSA.

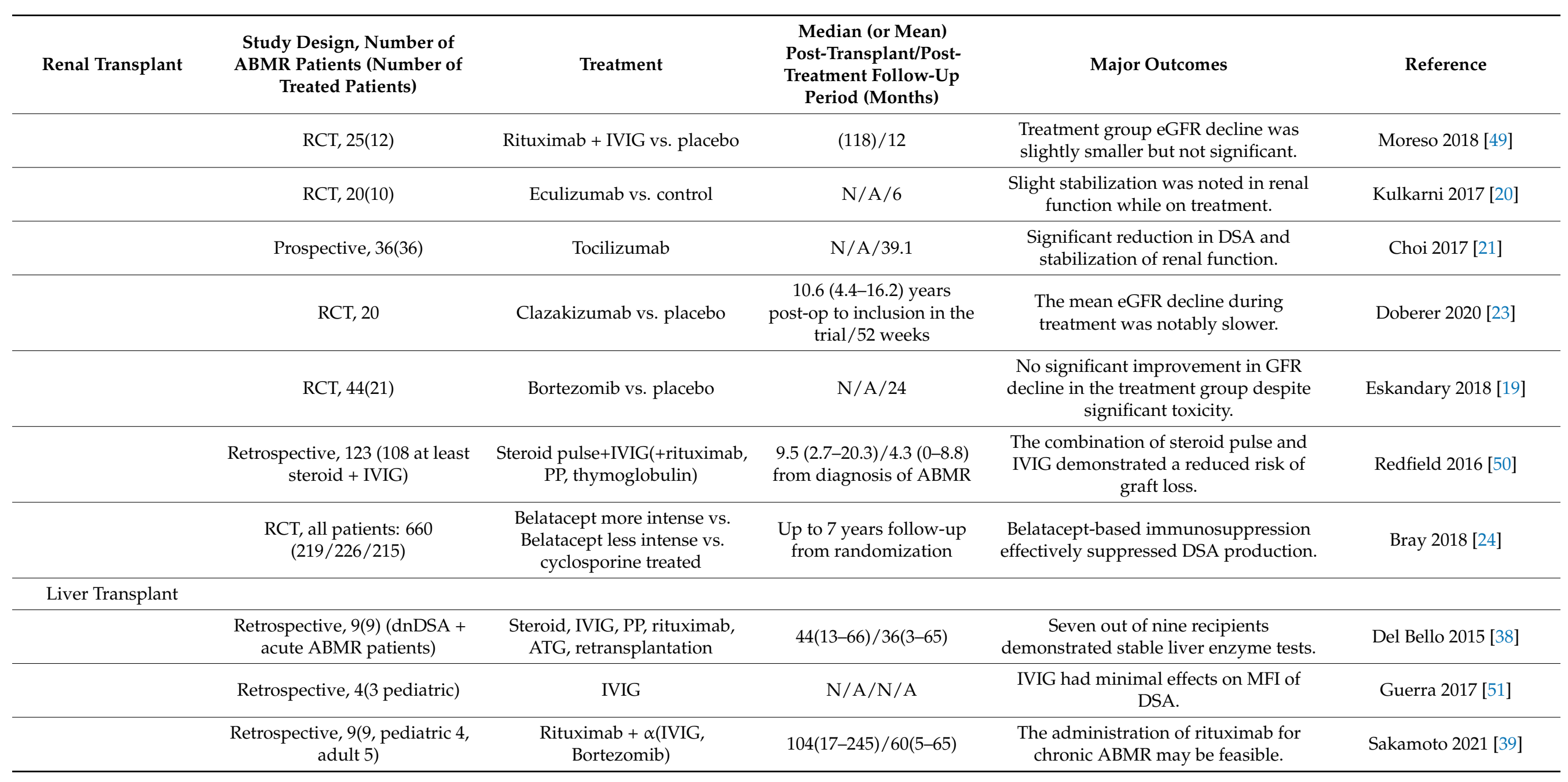


Table 1. Cont.

\begin{tabular}{|c|c|c|c|c|c|}
\hline Renal Transplant & $\begin{array}{l}\text { Study Design, Number of } \\
\text { ABMR Patients (Number of } \\
\text { Treated Patients) }\end{array}$ & Treatment & $\begin{array}{l}\text { Median (or Mean) } \\
\text { Post-Transplant/Post- } \\
\text { Treatment Follow-Up } \\
\text { Period (Months) }\end{array}$ & Major Outcomes & Reference \\
\hline \multicolumn{6}{|l|}{ PancreasTransplant } \\
\hline & $\begin{array}{l}\text { * Retrospective, various } \\
\text { treatments, } 9(4)\end{array}$ & $\begin{array}{l}\text { (nonstandard treatment for } \\
4 \text { patients) ATG, IVIG, PP, } \\
\text { alemtuzumab, pancreatectomy }\end{array}$ & $\begin{array}{c}21.7 \text { (range } 0.1-169.5 \text { ) } \\
\text { months / N/A }\end{array}$ & $\begin{array}{c}\text { Three patients received pharmacological } \\
\text { treatments and } 4 \text { out of } 9 \text { patients lost } \\
\text { their graft. }\end{array}$ & de Kort 2010 [40] \\
\hline & $\begin{array}{l}{ }^{*} \text { Retrospective, various } \\
\text { treatments, } 4(4)\end{array}$ & Steroids, IVIG, PP & $55.2 / \mathrm{N} / \mathrm{A}$ & $\begin{array}{l}\text { A quarter had graft failure } \\
\text { approximately } 2 \text { years after treatment. }\end{array}$ & Parajuli 2019 [43] \\
\hline & $\begin{array}{l}* \text { Retrospective, various } \\
\text { treatments, } 8(\mathrm{~N} / \mathrm{A})\end{array}$ & $\begin{array}{l}\text { Steroid pulse, IVIG, PP(five } \\
\text { sessions), Belatacept }\end{array}$ & $\mathrm{N} / \mathrm{A} / \mathrm{N} / \mathrm{A}$ & $\begin{array}{l}\text { Beyond the scope of this study to discuss } \\
\text { the optimal treatment. }\end{array}$ & Uva 2020 [46] \\
\hline
\end{tabular}

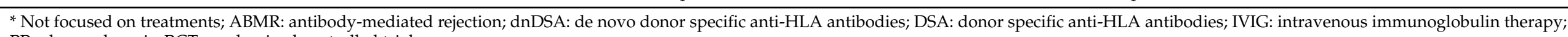

PP: plasmapheresis; RCT: randomized controlled trial. 


\section{An Overview of Recurrent Primary Disease}

Recurrent primary disease plays an important role in determining graft outcomes in almost all fields of organ transplantation. Discussing the recurrence of primary disease always requires a clear definition of the recurrence. Described here are several reports regarding recurrences of primary diseases in the different fields. It is important, however, to keep in mind that misleading reports can exist due to an unclear definition of recurrence. Thus, in this review, the forms of recurrences are determined as follows for the sake of clarity: pathological recurrence (PR), mild-to-moderate clinical recurrence (mCR), and severe clinical recurrence $(\mathrm{sCR})$ that results in end-stage organ failure.

\subsection{Kidney Transplantation}

There are many renal transplant recipients whose primary diseases are uncertain. In these cases, nephritis after transplantation cannot be recognized as recurrent or de novo nephritis precisely. However, recurrences of primary diseases certainly cause negative effects on graft survival rates. The management of recurrences should be considered seriously.

\subsubsection{IgA nephropathy}

Recurrent $\operatorname{IgA}$ nephropathy $(\operatorname{Ig} A N)$ is a crucial topic in renal transplant recipients with primary IgA nephropathy because a reported recurrence rate seems to be around $30 \%$ [52,53] at 10 years after transplant and as high as 50\% in biopsied patients [54,55]. Although many of these recurrent incidents are characterized by only PR with a benign clinical course, around $10 \%$ of these cases over the course of 10 years were associated with the aggressive deterioration of renal function: $\mathrm{sCR}$, resulting in graft loss. Thus, the control of IgAN recurrence remains an unmet need in the field of renal transplantation. Several factors may affect the pathogenesis of IgAN recurrence, such as low levels of immunosuppression, especially steroid avoidance [56] or HLA mismatch [57].

Cumulative data have suggested that circulating under-galactosylated or galactosedeficient (Gd) IgA1 and the subsequent generation of anti-GdIgA1 IgG $(\alpha \operatorname{IgA})$ play central roles in the pathogenesis of IgAN [58]. Suzuki et al. [59] reported that the levels of serum $\alpha \operatorname{Ig} A$ were closely associated with disease activity in native IgAN. As a progression of $\alpha \operatorname{Ig} A$ research, Julian and his colleagues [60] revealed glomerular deposition of $\alpha \operatorname{IgA}$ in native IgAN by means of the extraction of biopsy specimens, although not having enough tissue prevented individual analysis. In terms of IgAN recurrence after renal transplantation, Berthelot et al. followed 60 IgAN transplant patients, concluding that high serum GdIgA1 resulted in IgAN recurrence. Julian's group also demonstrated a similar result that serum normalized $\alpha$ IgA was an independent risk factor for IgAN recurrence [61]. In research described above, GdIgA1 and $\alpha \operatorname{IgA}$ were measured by the conventional ELISA method. By using the ICFA method, we measured $\alpha \operatorname{IgA}$ (serum/intragraft) and GdIgA1/ $\alpha \operatorname{IgA}$ immunocomplexes (intragraft) to investigate whether a causal relationship exists between $\alpha \operatorname{Ig} \mathrm{A}$ and IgAN recurrence. In this report, the IgAN recurrence group demonstrated significantly higher serum $\alpha \operatorname{IgA}$ levels at the time of recurrence confirmation. The IgAN recurrence group also exhibited higher intragraft $\alpha \operatorname{IgA}$ and relatively higher ICs than those of a non-IgAN recurrence group [62]. According to these reports, therefore, it is reasonable to believe that GdIgA1 and $\alpha \operatorname{IgA}$ are key molecules in $\operatorname{IgAN}$ recurrence and important targets to prevent recurrence. Nevertheless, there is no concrete evidence regarding therapeutics that target GdIgA1 and $\alpha \operatorname{IgA}$ at this moment.

Several studies suggest strategies as a part of prophylaxis to suppress IgAN recurrence, although no established induction therapy exists. As a prevention of IgAN recurrence, the Jikei group adopted elective tonsillectomy 1 year after renal transplantation and examined the relationship between tonsillectomy and serum GdIgA1 and GdIgA1 deposition in tonsils and kidneys [63]. They revealed that elective tonsillectomy reduced the rates of IgAN recurrence, coupled with decreased immunoreactivities of GdIgA1. This report supports an interesting tonsil-kidney circulation based on GdIgA1. 
Since HLA mismatch was suggested as a risk factor for the recurrence, there may exist a difference in outcomes between related or unrelated donor transplants [64]. Rodas et al. reported that full mismatches in HLA-B mitigated the recurrence of IgAN by examining 86 transplants, which included 38 living donor transplants [57].

Next, our concern is therapeutic modalities available in IgAN recurrence. Although there is no specific guideline for renal transplant recipients, many institutions basically follow native IgAN treatments consisting of steroid pulse [65], rituximab, tonsillectomy [63], and elimination of other exacerbating factors. A simple observation strategy often takes place for many PR cases, especially in elderly recipients, combined with lifestyle guidance. Either way, the current situation demands large prospective cohorts to establish a certain treatment strategy for IgAN recurrence.

\subsubsection{Focal Segmental Glomerulosclerosis}

FSGS is one of the main indications for renal transplant in relatively younger populations and recurs with a variety of rates from 10 to $60 \%$ within a couple of years after transplantation $[66,67]$. Due to its humoral-type pathogenesis, immediate recurrence is common and can occur within $24 \mathrm{~h}$ after transplant. As a typical example of clinical recurrence $(\mathrm{CR})$, massive proteinuria occurs immediately following reperfusion. At this initial point, fusion of the podocyte foot processes is the only finding by electron microscopic investigation. This progresses to a typical focal segmental sclerosis within a few months, which can be observed under an optical microscope. Under the current medical settings, a recurrence of FSGS significantly deteriorates graft survival and demonstrates around 30-60\% survival rate at 5 to 10 years after transplant [68-70].

We would like to examine a typical example that suggests that pathogenesis of FSGS is based on a circulating factor [71]. An sCR-deteriorated allograft in a FSGS recipient can regain its function in a different non-FSGS recipient after re-transplantation. Furthermore, plasma obtained from FSGS patients can reproduce FSGS phenomena in rats [72]. Subsequently, intensive study has revealed that the soluble urokinase-type plasminogen activator receptor (suPAR) is involved in the onset of FSGS [73]. Podocyte effacement is also closely related to serum suPAR levels, while suPAR levels reflect the response to therapy [74]. Therefore, it is reasonable to believe that reduction in suPAR results in a low CR rate.

Considering the possibility of immediate deterioration, it is reasonable to carry out prophylaxis measurements prior to transplant. Several approaches have been attempted as induction therapies, and these approaches can be roughly divided into B-cell depletion and apheresis. Although there is a report of these approaches having no preventive effects [75], the effectiveness of plasma exchange or apheresis is advocated by many institutions. On the other hand, B-cell depletion is often accomplished by anti-CD20 Abs. Prior to transplant, B-cell depletion followed by a series of plasma exchange or apheresis is one of the induction therapies that can be used to mitigate recurrence. These effects could be explained by the reduction in circulating factors, including suPAR. As a donor selection, a living related donor may have disadvantages in terms of recurrence. This study demonstrated a $6.6 \%$ increase in recurrence rates at 10 years after renal transplant in a living related donor compared to an unrelated donor [76].

Current therapeutics for CR consist of reinforcement of immunosuppressants, including steroid pulse, rituximab, and plasma exchange [77]. Although suPAR levels rebound relatively quickly, it has been reported that CR status was stabilized following these therapies [78]. Further investigation into suPAR and other humoral factors may provide more sophisticated therapeutic approaches for FSGS.

\subsubsection{Membranoproliferative Glomerulonephritis}

Membranoproliferative glomerulonephritis (MPGN) is evidenced by the thickening of capillary walls and diffuse mesangial cell proliferation under a light microscope. This disease can be divided into primary (unknown reason) and secondary (known reason) MPGN. Previously, MPGN had also been split into three distinct types based on patho- 
logical findings: sub-endothelial and mesangial immune deposits (type I, most common, mainly secondary MPGN); dense-deposit disease associated with the deposition of complement C3 without immunoglobulin deposition (type II); and a mixture of sub-epithelial and sub-endothelial immune deposits (type III, subtype of type I) [79]. Recently, this categorization has been replaced by a pathogenesis-based classification: (1) alternative complement pathway activation and (2) immunoglobulin-related type. C3 glomerulopathy belongs to classification (1) and is determined where glomerulonephritis is accompanied only by C3 deposition without $\mathrm{C} 1 \mathrm{q}$ or $\mathrm{C} 4$ deposition. $\mathrm{C} 3$ glomerulopathy has two forms: dense-deposit diseases and another C3-deposited glomerulopathy, which were previously categorized in type I and III [80,81].

Recurrence rates at $11.8 \%, 15.6 \%$, and $18.9 \%$ at 5,10 , and 15 years, respectively, after renal transplantation have been reported [70]. More prominently, C3 glomerulopathy exhibits higher than $80 \%$ recurrence rates in a small case series (19 patients) [82]. About 50 to $70 \%$ high rates of graft failure within 5 years after recurrence were observed in MPGN recurrent cases, especially in dense-deposit disease [70,82]. Thus, it is pivotal to explain these serious outcomes after recurrence for renal transplant candidates in advance. Furthermore, we should seek circumstances where recurrence is less likely to occur. An Israeli group reported that $19 \%$ recipients of MPGN type I recurred over a $118 \pm 61$ months follow-up period, and HLA B49 and DR4 were considered to be risk alleles. This research also suggests that an unrelated donor is preferred for transplant due to MPGN, based on the finding that higher rates $(25 \%)$ of living related to donor renal transplant recipients recurred MPGN rather than to unrelated donor transplant $(0 \%)$, although another study denied the participation of donor category in recurrent MPGN [76]. In addition, recurrent MPGN, again, clearly showed worse graft survival [83]. Although an optimal induction therapy has not been determined, a B-cell targeted immunosuppressive approach appears to be logical.

The strategies for recurrence of MPGN are also similar to those for the primary disease, which consist of plasma exchange, rituximab, steroid pulse, or eculizumab [84]. Nevertheless, given the significant rates of recurrence and graft failure, it is crucial to inform patients of the outcomes of renal transplantation and to establish effective therapeutic strategies.

\subsubsection{Membranous Nephropathy}

Membranous nephropathy (MN) occurs as a pure glomerular-specific autoimmune disease, as well as a secondary disease due to a systemic condition such as infections, malignant disorders, autoimmune diseases, etc. This entity is induced by immunocomplex deposition in the sub-epithelial area of the glomerular basement membrane [85]. The primary cause seems to be a development of Abs against podocytes. The major Abs that have been identified include anti-phospholipase A2 receptor antibodies (PLA2R) [86] and thrombospondin type-1 domain-containing 7A antibodies (THSD7A) [87].

Recurrence rates at 10\% (5-year), 16\% (10-year), and 18\% (15-year) were observed, which are similar to those of MPGN discussed above. The recurrence rates could be higher (up to $40 \%$ ) when including PR found by a protocol biopsy [88]. PR is likely to occur within 1 year after transplant and has a possibility of recurring as early as 2 weeks post-transplant. The secondary MN displayed relatively low rates of recurrence, provided that the primary diseases were well controlled. The recurring $\mathrm{MN}$ could result in notable graft failure rates of up to $60 \%$ [70]. A lack of consistency in the graft failure rates in recurring cases would indicate that the studied population was not heterogenous.

Regarding recurrence and autoantibody levels, Kattal et al. investigated $26 \mathrm{MN}$ recipients according to their anti-PLA2R levels and revealed that anti-PLA2R levels were $83 \%$ and $42 \%$ of the positive and negative predictive values, respectively, for recurrent MN after transplant [89]. In addition, anti-THSD7A also could induced a recurrence of $\mathrm{MN}$, as evidenced in a case report accompanying an investigation into a murine MN model [90]. 
Therefore, autoantibody levels may enable us to stratify recipients into appropriate recurrent risk groups.

In order to prevent recurrence, many researchers may seek to perform treatments with induction therapy prior to transplant. However, at present, there appears to be no reliable induction therapy for meaningfully suppressing recurrence. Furthermore, it is still controversial whether unrelated donors are advantageous to recurrent MN [76,91].

The management of recurring $\mathrm{MN}$, again, follows primary $\mathrm{MN}$ treatments consisting of treatments for nephrotic syndrome and decreased renal function.

Features of IgAN, FSGS, MPGN, and MN with overall recurrence rates are described in Table 2.

Table 2. Overall recurrence rate, other characteristics, available prophylaxis, and treatments in glomerulonephritis after kidney transplantation.

\begin{tabular}{|c|c|c|c|c|}
\hline & IgA Nephropathy & $\begin{array}{l}\text { Focal Segmental } \\
\text { Glomerulosclerosis }\end{array}$ & $\begin{array}{l}\text { Membranoproliferative } \\
\text { Glomerulonephritis }\end{array}$ & $\begin{array}{l}\text { Membranous } \\
\text { Nephropathy }\end{array}$ \\
\hline Recurrence Rate & $\begin{array}{c}\text { About } 30 \% / 50-120 \text { months } \\
(28.6 \% / 121 \pm 69 \text { months } \\
\text { [52], 34.9\%/median } 49 \\
\text { (range } 4-213) \text { months [53]) }\end{array}$ & $\begin{array}{c}\text { Differ widely between } \\
\text { reports } \\
(10.4 \% \text { / median } 6.1 \text { years } \\
\text { (follow-up) [66], } \\
46.7 \% / 2.2 \pm 1.8 \text { years [92], } \\
57.6 \% / \text { median } 1.25 \text { ( } 1 \text { day } \\
\text { to } 30 \text { months) months [67]) }\end{array}$ & $\begin{array}{c}\text { Differ widely between } \\
\text { reports } \\
(11.8 \%, 15.6 \% \text {, and } 18.9 \% \\
\text { at } 5,10, \text { and } 15 \text { years [70], } \\
84.2 \% / 76 \text { months } \\
\text { follow-up (C3 } \\
\text { glomerulopathy) [82]) }\end{array}$ & $\begin{array}{c}\text { Differ widely between } \\
\text { reports } \\
(10 \%, 16 \% \text {, and } 18 \% \text { at } 5, \\
10 \text {, and } 15 \text { years }[70], \\
11.4 \% \text { / median } 3.6(1.0-4.7) \\
\text { years }[93], 44 \% / 13.6 \\
\text { months }[88])\end{array}$ \\
\hline $\begin{array}{l}\text { Graft loss due to clinical } \\
\text { recurrence }(\%)\end{array}$ & $\begin{array}{l}10.8 \% \text { at } 10 \text { years [53], } \\
21.4 \% / 130.8 \pm 10.6 \text { months } \\
\text { follow up periods [94], 58\% } \\
\text { at } 5 \text { years [ } 70]\end{array}$ & $\begin{array}{l}\text { Differ widely between } \\
\text { reports } \\
(43 \% \text { at } 5 \text { years [70], } \\
39 \% / \text { median } 5 \text { years [69], } \\
9 \% / \text { median } 29.5 \text { months [67]) }\end{array}$ & $\begin{array}{l}\text { About } 50-70 \% / \sim 5 \text { years } \\
\text { (56.3\%/median } 42 \text { months } \\
\text { (C3 glomerulopathy) [82], } \\
70 \% \text { at } 5 \text { years [70]) }\end{array}$ & $\begin{array}{c}\text { About } 50-60 \% / \sim 5 \text { years } \\
(47.4 \% \text { allograft } \\
\text { loss } / \text { median } 3.6(1.0-4.7) \\
\text { years [93], } \\
59 \% \text { at } 5 \text { years }[70])\end{array}$ \\
\hline Pathogenesis & $\begin{array}{c}\text { Galactose-deficient IgA1, } \\
\text { anti- galactose-deficient } \\
\text { IgA1 IgG, immunocomplex }\end{array}$ & $\begin{array}{l}\text { Circulating permeability } \\
\text { factors, such as suPAR }\end{array}$ & $\begin{array}{l}\text { Alternative complement } \\
\text { pathway activation or } \\
\text { immunoglobulin } \\
\text { deposition }\end{array}$ & $\begin{array}{l}\text { Anti-phospholipase A2 } \\
\text { receptor, or } \\
\text { thrombospondin type-1 } \\
\text { domain-containing 7A } \\
\text { antibodies, etc. }\end{array}$ \\
\hline $\begin{array}{l}\text { Risk factors of } \\
\text { recurrence based on } \\
\text { donor type/factors }\end{array}$ & HLA match, related donor & Related donor & $\begin{array}{l}\text { Related donor } \\
\text { (controversial) }\end{array}$ & $\begin{array}{l}\text { Related donor } \\
\text { (controversial) }\end{array}$ \\
\hline $\begin{array}{c}\text { Prophylaxis (Induction } \\
\text { Therapy) }\end{array}$ & Tonsilectomy & $\begin{array}{l}\text { Plasma exchange, } \\
\text { apheresis, rituximab }\end{array}$ & $\begin{array}{l}\text { Plasma exchange, } \\
\text { rituximab }\end{array}$ & $\mathrm{N} / \mathrm{A}$ \\
\hline Treatments & $\begin{array}{l}\text { Steroid pulse, rituximab, } \\
\text { tonsilectomy }\end{array}$ & $\begin{array}{l}\text { Plasma exchange, } \\
\text { apheresis, rituximab }\end{array}$ & $\begin{array}{c}\text { plasma exchange, } \\
\text { rituximab, steroid pulse, } \\
\text { or eculizumab }\end{array}$ & Steroid pulse, Rituximab \\
\hline
\end{tabular}

\subsubsection{Lupus Nephritis}

Generally, lupus nephritis is diagnosed in various rates up to $70 \%$ of patients with systemic lupus erythematosus (SLE) [95]. Typically, the onset of nephritis is observed within 3 to 5 years after SLE diagnosis [96]. Pathologically, nuclear antigens, especially DNA and anti-nuclear/DNA complement-binding IgG, seem to play important roles in the onset of lupus nephritis [97].

CR after renal transplantation can be less than 5\% [98]. It can be argued that pathological activity decreases at the time of renal failure and the introduction of immunosuppression after transplant also suppresses disease activity. A large study for lupus nephritis indicated equivalent outcomes relative to non-lupus nephritis renal transplant recipients [99]. Deegens et al. reported that one patient out of 23 recipients exhibited lupus nephritis, albeit with no biopsy evidence due to coagulopathy [100]. However, it is true that the recurrence rate largely relies on the executing rates of biopsy procedures. In fact, PR increased by up to $50 \%$ when less aggressive types of histological changes-class II, III, etc.-are included [101]. Taken together, PR seems to be relatively common, but does not affect overall outcomes. Therefore, it is reasonable to perform renal transplant for lupus-related renal failure. 
Regarding induction therapy, there is no standard recommendation at present. However, it is recommended that renal transplant should be performed after the introduction of dialysis therapy for several months, with the dosage of prednisolone decreased to less than $10 \mathrm{mg} /$ day [102]. From this perspective, preemptive renal transplant may not be feasible, especially in cases with rapid progression to renal failure. When considering preemptive transplant, disease activities assessed by anti-nuclear Abs and anti-double strand DNA Abs, CH50, C3, etc., should be carefully reviewed.

For CR cases, treatment plans consist of steroid pulse, increasing the dose of mycophenolate mofetil or substituting cyclophosphamide for mycophenolate mofetil, and anti-CD20 Abs [103].

4.1.6. Anti-Neutrophil Cytoplasmic Autoantibody or Anti-Glomerular Basement Membrane Antibody Positive Rapidly Progressive Glomerulonephritis

Both anti-neutrophil cytoplasmic autoantibodies (ANCA) and anti-glomerular basement membrane (GBM) antibody-positive rapidly progressive glomerulonephritis (RPGN) are categorized as acute progressions to renal failure accompanied with hematuria, proteinuria, and anemia. Clinical RPGN comprises a variety of diseases such as part of IgAN, thrombotic microangiopathy, acute interstitial nephritis, etc. This section features ANCA-related nephritis and anti-GBM-Abs-related nephritis [104].

Around 10\% recurrence rates have been reported for ANCA-related nephritis after transplant, and one-third of these resulted in graft loss over the first five years [105]. Although ANCA titers are utilized to assess disease activity, several studies indicate that the levels of ANCA could not be relied upon to assess recurrence [106,107]. Nonetheless, the activity of primary disease is considered important for controlling recurrence. Thus, it is sensible to wait for renal transplant at least one year after the activity becomes under control [108].

On the other hand, the recent recurrence rates for anti-GBM-Abs-related nephritis seem to be less than $5 \%$, which is lower than that of ANCA-related nephritis $[109,110]$. Interestingly, the step for waiting for remission is similar, but a decrease in anti-GBM Abs for at least 12 months consecutive is also required for safe renal transplant [111].

It is feasible to perform renal transplants for these two RPGN-induced renal failures when indicated due to the relative lower rates of recurrence.

Clinically important information regarding lupus nephritis, anti-ANCA, and antiGBM RPGN is summarized in Table 3.

Table 3. Summary of recurrence rate and graft survival in patients with recurrence in lupus/ANCA/anti-GBM nephritis following kidney transplantation.

\begin{tabular}{|c|c|c|c|}
\hline & Lupus Nephritis & ANCA Related Nephritis & $\begin{array}{c}\text { Anti-GBM Abs Related } \\
\text { Nephritis }\end{array}$ \\
\hline Recurrence Rate & $\begin{array}{l}\text { Vary between reports due to } \\
\text { the frequency of biopsies, } \\
30 \% / 6.8 \pm 4.9 \text { (range, } \\
3 \text { months-20 years) [101], } \\
4.3 \% / 74.2 \pm 72.2 \text { months [100] }\end{array}$ & $\begin{array}{c}2.8 \% \text { per patient year, } \\
10 \% / \text { the first } 5 \text { years post-op } \\
\text { [105], } 4.7 \% \text { /median } 5.5 \\
\text { years }[106]\end{array}$ & $\begin{array}{c}3.9 \% / \text { median } 6.4 \text { years [109], } \\
2.7 \%[110]\end{array}$ \\
\hline $\begin{array}{l}\text { Graft loss due to clinical } \\
\text { recurrence }(\%)\end{array}$ & $\begin{array}{c}2 \% / 6.8-4.9 \text { (range, } 3 \\
\text { months-20 years) [101], } \\
1 / 31(3 \%) \text { graft losses among } \\
80 \text { lupus transplant was } \\
\text { caused by recurrence [112] }\end{array}$ & $\begin{array}{l}\text { Four out of } 11 \text { recurrent cases } \\
\text { lost theirgrafts within } 5 \text { years } \\
\text { of transplantation [105], } \\
2.8 \% / \text { median } \\
5.5 \text { years [106] }\end{array}$ & $\begin{array}{c}3.9 \% / \text { median } 6.4 \text { years [109], } \\
0.9 \%[110]\end{array}$ \\
\hline Pathogenesis & Type III allergy & $\begin{array}{l}\text { Neutrophil activation due to } \\
\text { proteinase } \\
\text { 3/myeloperoxidase-ANCA } \\
\text { etc. [113] }\end{array}$ & Anti-GBM Abs(type II allergy) \\
\hline Recommendation & $\begin{array}{l}\text { Better to perform kidney } \\
\text { transplant after introduction } \\
\text { of dialysis therapy for several } \\
\text { months, and being able to } \\
\text { reduce prednisolone } \\
<10 \mathrm{mg} / \text { day }\end{array}$ & $\begin{array}{l}\text { Wait for renal transplant at } \\
\text { least } 12 \text { months after the } \\
\text { disease activity becomes } \\
\text { under control. }\end{array}$ & $\begin{array}{l}\text { Confirm a decrease in } \\
\text { anti-GBM Abs for at least } \\
\text { consecutive } 12 \text { months }\end{array}$ \\
\hline
\end{tabular}




\subsubsection{Amyloidosis and Mimickers}

Amyloidosis is a systemic disease and a relatively rare entity for renal transplantation. Amyloid deposition is observed under the electron microscopy at around 5-12 nm fibrils, which are $\beta$-pleated sheets [114]. In addition, a positive Congo red stain and an apple-green birefringence with polarized light are often used for confirmation [115]. Mass spectrometry became a useful tool for distinguishing the following subtypes [116].

$\mathrm{AL}$ (fibrils due to immunoglobulin light chain clonal production); AA (serum amyloid A congregation, secondary amyloidosis); ATTR (hereditary amyloidosis, genetic mutation of misfolding-prone protein (mainly transthyretin)); and ATTRwt (wild-type transthyretin misfolding). Responsible proteins of ATTR include apolipoprotein A-I, A-II, lysozyme, fibrinogen, and cystatin C, etc., in addition to transthyretin $[117,118]$.

Although amyloidosis negatively impacted the patients' graft survival, the overall outcomes were equivalent with diabetes mellitus (DM) or elderly ( $>65$ years) recipients after renal transplantation. Around $15 \%$ recurrence rates had been reported, depending on the subtype of amyloidosis, and significantly affected patients' survival. Regarding AL amyloidosis, a complete hematologic response seems to be key in achieving better survival [119] and acceptable outcomes (median duration to graft loss: 10.4 years), whilst patients with partial or no response demonstrated inferior outcomes (5.5 years) [120]. Apolipoprotein A-I and lysozyme amyloidosis showed better graft survival, with 13.1 years at median [119]. These studies suggest that renal transplant outcomes largely rely on the type of primary amyloidosis. Therefore, at least, it is reasonable to evaluate patients carefully and manage the primary amyloidosis appropriately in order to mitigate the risk of recurrence when considering renal transplant for amyloidosis.

On the other hand, as a mimicker, fibrillary glomerulonephritis (FGN) shares several common characteristics both clinically and histologically: nephrotic or nephrotic syndrome, deposits of $12-24 \mathrm{~nm}$ fibrils, and occasionally positive Congo red stain (4\%). FGN is characterized by DnaJ homolog subfamily B member 9 as an auto-antigen [121] and possibly recurs after transplant with the rate at around 20\% [122]. Thus, it is pivotal to make a correct diagnosis in confusing cases by using mass spectrometry.

In addition to recipients diagnosed with amyloidosis, it is essential to keep renal amyloidosis in mind in cases of new-onset proteinuria or nephrotic syndrome following renal transplantation for an unknown primary disease, since a routine pathological screening may not identify the early signs of recurrent amyloidosis.

\subsection{Liver Transplantation}

After liver transplantation, a variety of medical problems might occur, such as renal damage, new onset of DM, etc., in addition to rejection and infection. Furthermore, primary disease recurrences are another significant issue. There are at least three major mechanisms by which a primary disease recurs in liver grafts. The first category is a recurrence in the same manner as the primary disease, for example, primary biliary cholangitis or primary sclerosing cholangitis. Secondly, a recurrence of hepatitis due to a virus that is responsible for the primary hepatitis belongs to this category. Third, this category contains recurrences of tumors in liver graft. It can be recognized as primary tumor metastases to liver grafts.

\subsubsection{Viral Hepatitis}

Although viral hepatitis B and C have been the leading reasons for adult liver transplants [123], a recent rapid increase in nonalcoholic steatohepatitis has rearranged this trend [124].

Regarding hepatitis B virus (HBV) reactivation following transplant, there are two main distinctive situations. The first instance is HBV hepatitis in HBsAg (hepatitis B surface antigen)-positive recipients, whereas $\mathrm{HBV}$ transfer from a donor who is $\mathrm{HBs} A g$ negative/hepatitis B core antibodies (anti-HBc Abs)-positive is another example. From the perspective of recurrence, former conditions will be discussed here. 
For recipients with HBV infection, inappropriate prophylaxis results in HBV reinfection of liver grafts. Following the removal of the infected liver, the reinfection is established with HBV remaining in the recipient's blood stream. This trend seems to be more apparent in recipients with preoperative HBV-DNA positive than HBV-DNA and hepatitis B e antigen (HBeAg) double-negative cases. Eighty-three percent of preoperative HBV-DNA positive recipients had serums that became HBsAg-positive after surgery. Nevertheless, HBV-DNA and HBeAg double-negative cases also showed an HBsAg resurgence in 58\% of recipients [125]. Therefore, HBV exists in recipients, albeit with negative results for HBV-DNA. It is well known that the outcomes of HBV reinfection have significant negative effects on liver grafts: rapid progression to cirrhosis [126]. As prophylaxis strategies, initially, hepatitis B immunoglobulin or lamivudine administration had been implemented. However, higher than $30 \%$ reactivation was confirmed despite prophylaxis $[125,127]$. Thereafter, it was proved that hepatitis B immunoglobulin and lamivudine coadministration was effective enough to suppress reactivation, with a rate of $0-10 \%[128,129]$. Consequently, it became a standard practice to apply preoperative lamivudine treatment, intraoperative hepatitis B immunoglobulin IV, and postoperative coadministration.

Although hepatitis $\mathrm{C}$ virus (HCV) has spread worldwide, the introduction of directacting antivirals (DAA) has completely changed its management after liver transplantation [130]. In addition, DAA provides an opportunity to expand a donor pool to the $\mathrm{HCV}$-positive population [131]. As a natural course of liver transplant for HCV, the rates of HCV-recurrent infection are significantly high and typically occur soon after surgery, while only $5 \%$ of recipients may escape from recurrence. In many cases, HCV RNA becomes detectable two to four weeks after transplant. Subsequently, many recipients show histological chronic hepatitis [132,133]. Before the introduction of DAA, it was believed that these factors might affect the overall outcomes of liver transplants. Surprisingly, these negative influences may be limited to slight-to-moderate inferior outcomes in 5-year patient survival rates [134]. Conversely, several studies have reported that HCV recurrence possibly caused serious outcomes, such as fibrosing cholestatic hepatitis [135], immediate progression to cirrhosis [136], or deteriorated patient survival [137].

Before the emergence of DAA, several treatment strategies were reported. From the 1990s, interferon therapy commenced [138]. Ribavirin was added in the 2000s [139] and was later improved by Peg-interferon [140]. However, the sustained virological response (SVR) after transplant remained only around 10-40\%, which was far below acceptable rates [141,142]. In 2011, telaprevir was approved as a first-generation proteinase inhibitor and established as a triple-drug treatment [143]. The second generation simeprevir, emerged in 2013, and the regimen further improved [144].

Next, in 2014, the interferon-free DAAs, asunaprevir, and daclatasvir were developed with successfully high SVRs [145]. Conversely, it is true that candidates for liver transplant may have belonged to a category where preoperative treatment was ineffective or impossible due to refractory mutated HCV or patients' other conditions. Thus, SVRs after transplant were inevitably lower than those of native HCV patients [146].

Considering these serious consequences, the effective DAA introduction was significant, especially after the emergence of sofosbuvir and ledipasvir. As the SVRs had reached nearly $100 \%$ both in native HCV and liver transplant patients $[147,148]$, DAA introduction after liver transplant became a standard therapy. Furthermore, for recipients with renal failure, cirrhosis, or prior DAA failure, the effectiveness of glecaprevir and pibrentasvir has been reported [149].

\subsubsection{Malignant Tumor}

Liver transplantation is indicated for end-stage liver disease with tumors or unresectable malignant liver tumors under certain conditions. Hepatocellular carcinoma (HCC) is a representative tumor that is most frequently indicated for liver transplantation. Originally, it is well known that the outcomes of liver transplantation for HCC without staging were inferior to those of other primary diseases without HCC [150]. This is primarily 
because HCC recurs in transplanted liver grafts in immunocompromised patients. Thus, liver transplantation should proceed in circumstances where HCC is not disseminated to the outside of the liver. To overcome the recurrence of HCC, the Milan criteria was clinically introduced worldwide [151]. However, a certain patient group demonstrated the equivalent outcomes, albeit with deviation from the Milan criteria. The criteria were then modestly expanded to the University of California, San Francisco (UCSF) criteria, which showed a $75 \%$ survival rate in 5 years [152]. The Kyoto group also expanded the eligibility for liver transplantation with an excellent survival rate of $82 \%$ and a low recurrence rate of $7 \%$ at 5-years post-transplant [153]. It is noteworthy that the Kyoto group not only applied tumor size and numbers, but also serum des-gamma-carboxy prothrombin levels as an assessment for tumor activities. Recently, there have been further efforts to establish several other safer models, such as the hazard associated with liver transplantation for hepatocellular carcinoma which incorporates a dynamic $\alpha$-fetoprotein response [154].

Early stage unresectable cholangiocarcinoma is also considered as an indication for liver transplantation. Cholangiocarcinoma is the second most common liver cancer and pathophysiologically divided into two different groups: extrahepatic cholangiocarcinoma and intrahepatic cholangiocarcinoma. Among extrahepatic cholangiocarcinoma, perihilar cholangiocarcinoma may be an indication for liver transplantation, whilst liver transplantation is not indicated for distal cholangiocarcinoma given its location [155]. LT can only be a valid treatment plan if it can promise a better survival rate compared to liver resection. In order to achieve this, the Mayo Clinic protocol that was originally reported in 2000 has been supported. In summary, liver transplantation is performed following neoadjuvant chemoradiotherapy, which consists of extra-beam and transcatheter radiation therapy and intravenous 5-FU administration [156]. Based on experience, elevated CA19-9, encased portal vein, and non-radical resection were identified as predictors of recurrence following liver transplantation [157]. On the other hand, several initial studies regarding intrahepatic cholangiocarcinoma seem to be difficult to interpret since the pathological conditions of recipients were not sufficient. However, recent studies show that liver transplantation for very early intrahepatic cholangiocarcinoma-a single tumor measuring less than $2 \mathrm{~cm}$-promises acceptable outcomes, with a 73\% 5-year patient survival rate [158]. In summary, these results were obtained from incidental pathological findings in recipients with cirrhosis or initial misinterpretation as HCC. Thus, initial diagnosis such as very early intrahepatic cholangiocarcinoma should first be considered for liver resection. However, if liver resection is not an option, as with portal hypertension, etc., liver transplantation might be the last resort.

\subsubsection{Primary Biliary Cholangitis}

Primary biliary cholangitis (PBC) is categorized as a cholestatic liver disease accompanied by autoimmune features. These features comprise anti-mitochondrial Abs (AMA) positivity ( $>90 \%$ of patients), targeting anti-E2 domain of pyruvate dehydrogenase complex Abs [159], and meaningful overlap with other autoimmune disorders, such as Sjogren's syndrome and thyroiditis, etc. [160]. Thus, PBC is recognized as part of a systemic autoimmune condition. Histologically, PBC is characterized by a chronic destructive form of nonsuppurative granulomatous lesions with or without lymphocytes-infiltrate cholangitis in small-sized and medium-sized biliary trees [161].

With the introduction of ursodeoxycholic acid (UDCA) in the early stages of PBC, the resulting rates of liver transplant or death improved to $6 \%$ and $22 \%$ at 10 and 20 years, respectively, after the onset of PBC [162]. The outcomes of liver transplant are generally good, with around $80 \%$ and $70 \%$ survival rates reported at 5 and 10 years, respectively $[163,164]$. Interestingly, similar outcomes have been reported with deceased and living liver transplant donors [165]. The rates of recurrent PBC appear to vary depending on whether recipients received prophylactic UDCA administration and the frequency of liver biopsies. Recurrence rates at $10 \%$ to $20 \%$ have been reported in recipients with prophylaxis during an approximately 10-year follow-up period $[166,167]$, whereas patients without 
prophylaxis have demonstrated greater than $30 \%$ recurrence rates over the same time period $[168,169]$. These studies support that UDCA is effective for the majority of patients with recurrence, but there were no significant improvements in histological changes and patients' survival [169].

Diagnosis of recurrent $\mathrm{PBC}$ is largely reliant on histological findings, since only around $10 \%$ of recurrent $\mathrm{PBC}$ patients demonstrate classic symptoms of $\mathrm{PBC}$, i.e., pruritis, jaundice, xerostomia, or keratoconjunctivitis sicca, etc. In order to standardize recurrent PBC, pathological features combined with the existence of AMA and elevated IgM are often adopted clinically. Pathological features include the following four findings: 1 . epithelioid granulomas called florid lesions, 2. lymphoplasmacytic infiltration, 3. lymphocytes aggregation, and 4 . bile duct injury. Definite recurrent PBC is defined by having all 3-4 pathological features, while conditions meeting $2 / 4$ criteria are considered as probable recurrent PBC [170].

Citing definite risk factors for recurrence of $\mathrm{PBC}$ is still controversial, although several studies suggest that immunosuppressants, HLA alleles, HLA mismatch, recipient/donor age, and gender play a role, which appear to be feasible from the perspective of the behavior of autoimmune nature. Manousou et al. reported that therapy with cyclosporin and azathioprine in combination had preventive effects on the recurrence of PBC, although cyclosporin and tacrolimus alone had minimal influence [168]. Egawa et al. also suggest that there is superiority in conversion to cyclosporin from tacrolimus within 1 year to decrease the risk of recurrence, albeit with a disadvantage of cyclosporin as a primary calcineurin inhibitor [171]. This research enumerated several other risk factors: serum IgM $554 \mathrm{mg} / \mathrm{dL}$ or higher and donor-recipient sex mismatch. Recent meta-analysis from six retrospective studies showed tacrolimus inferiority and UDCA protective effects for the recurrence of PBC [172].

Regarding disease activity of recurrent $\mathrm{PBC}$, it basically exhibits an indolent style that barely requires re-transplantation and tends not to affect long-term outcomes. A Japanese multicenter study showed that PBC recurrence rarely became an indication for re-transplantation after analyzing seven re-transplant cases from 516 liver transplant recipients of PBC [173], while Charatcharoenwitthaya et al. reported that two out of thirtyeight recurrent cases required re-transplantation [169]. Taken together, it can be argued that $\mathrm{PBC}$ recurrence seldom results in graft loss.

\subsubsection{Primary Sclerosing Cholangitis}

Primary sclerosing cholangitis (PSC) is characterized by both intra-hepatic and extrahepatic multiple or diffuse bile duct stenoses, which result in a chronic cholestatic conditions associated with cirrhosis. Pathogenesis of PSC remains unclear, but, as with other multifactorial diseases, genetic factors along with environmental factors may play a role in its onset. Notable findings include a strong association of up to $80 \%$ with inflammatory bowel disease, especially ulcerative colitis [174]. In addition, PSC increases the risk of primary liver cancer, especially cholangiocarcinoma, by up to 1500 times compared with the general population and increases the annual morbidity rate by $0.5 \%$ [175]. At present, liver transplantation is the only established therapy for PSC. The overall survival rates without liver transplant in PSC patients were 78 and $60 \%$ at 10 and 20 years, respectively, following the onset of PSC [176].

The outcomes of liver transplantation for PSC differ from relatively poor to acceptable graft survival rates. From the European Liver Transplant Registry, 80, 69, and 57\% graft survival rates at 1,5 , and 10 years, respectively, were reported [163], while U.S. data showed $86.5,78$, and $71.5 \%$ for the same time periods [164]. Although several discrepancies exist, the outcomes are generally worse than those for liver transplants for other cholestatic diseases. It can be argued that recurrent PSC in transplanted livers is one of the reasons for the worse outcomes.

Periductal concentric fibrosis (onion skin fibrosis) accompanied with lymphocyte infiltration is a well-known histological finding. However, this typical feature is not often 
observed in PSC clinically. In order to diagnose PSC, cholangiography is considered the most important step. A beaded or "pruned tree" appearance and band-like strictures are characteristic features of PSC. Recurrent PSC is determined in PSC recipients who demonstrate these cholangiography findings or pathologies, with the exception of cases of hepatic artery thrombosis or other similar conditions [177]. Pathological features are considered particularly important in the diagnosis. Recurrence rates of around $20 \%$ have been reported, especially when less than a median of 5 years has passed since transplant [178-180].

The discrepancies in the reported incidences of recurrence may reveal some risk factors, although several risk factors have been reported from various institutions. These risk factors are considered to be possible issues for grafts, recipients-donor relations and recipients. Regarding liver grafts, marginal or extended donor criteria grafts may exhibit a higher incidence of recurrence [179]. Meaningful insights can also be obtained from living donor liver transplants. Notably, related (parent/child) pairs may show higher recurrence rates, and this tendency is clearer if recipients are followed-up longer: The hazard ratio is 3.12 ( $>12$ months follow-up) [181]. Another study suggested higher recurrence rates in living donor liver transplants, compared to deceased donor transplant [182]. However, a multi-center cohort study denied the impact of donor type, albeit without collecting adequate HLA data [183].

In relation to recipient issues, several factors have been discussed, such as inflammatory bowel disease, rejection/immunosuppressants, younger age, and high MELD scores, etc. Of these, topics regarding inflammatory bowel disease are often discussed. Given the "leaky gut" hypothesis, unchanged bowel bacterial flora or substances from those after transplant may evoke the same pathological condition in transplanted liver grafts [184]. Thus, pretransplant colectomy with a remission of inflammatory bowel disease may confer PSC pathogenesis-free circumstances. Rejection, especially a refractory one, also imposes a higher risk of recurrence that may be explained by the fact that PSC and rejection share the same immunological pathways [185]. Taken together, several institutions seem to apply the following as clinically acceptable strategies: (1) avoidance of a first-degree relative as a donor and reliance on a deceased donor, if trusting the results that showed living donor inferiority, and (2) minimal withdrawal of immunosuppression.

Recurrent PSC tends to demonstrate CR style and demonstrates inferior outcomes (graft loss) that require re-transplantation with high probabilities (30-70\%) compared to recurrent PBC or autoimmune hepatitis $[181,183]$. These results suggest that recurrent PSC progresses vehemently to graft loss. As with native PSC, no standard therapy has yet been established for recurrent PSC except for re-transplantation, although biliary tract drainage can be attempted in several cases as rescue therapy.

\subsubsection{Autoimmune Hepatitis}

Autoimmune hepatitis (AIH) is an inflammatory, basically progressive, autoimmune disease that mainly affects middle-aged women (but possibly all ages and both genders) due to uncertain causes. The disease progression seems to rely on environmental triggers and genetic factors [186]. Although no disease-specific markers have been identified, several autoantibodies have been recognized in AIH: anti-nuclear, anti-smooth muscle, anti-liver kidney microsome, and anti-liver cytosol antigen type I. Based on these serological markers, AIH can be separated into type I (anti-nuclear or anti-smooth muscle Abs, or both) and II (anti-liver kidney microsome Abs) AIH [187]. In addition, the existence of type III AIH (anti-soluble liver antigens Abs) has been advocated [188], although the characteristic of this entity overlaps with type I AIH [187]. AIH is also characterized by mildly elevated serum IgG levels and interface hepatitis or plasma-lymphocytic infiltration. In terms of treatment, the first recommendation is corticosteroids followed by azathioprine and mycophenolate mofetil in that order [189]. If appropriate therapies are provided, the long-term outcome of AIH generally provides sufficient life expectancy. However, compared to other chronic liver diseases, the lack of these interventions results in relatively rapid progression to cirrhosis and liver failure, which requires liver transplant [190]. 
The recurrence of AIH after liver transplantation was initially reported with the rate of $26 \%$, including PR to CR, by the Pittsburgh group [191]. Several other studies reported similar results of around 30 to $40 \%$ recurrence rates [192,193], including ambiguous cases. According to a recent systematic review, 8-12\% and 36-68\% PR to CR have been reported in one and five years, respectively, after liver transplant [194]. PR, with an indolent clinical course, may make up a large part of the recurrence. Although there is no firm consensus regarding recurrence, the diagnosis of recurrence largely relies on clinical manifestations: abnormal liver function tests, positive autoantibody status, high gamma globulinemia, and pathological findings (lymphoplasmacytic infiltration to portal area, central perivenulitis, interface hepatitis, and foci of necrosis) without evidence of endothelialitis and ductulitis, with the exclusion of rejection and viral infection. Notably, it is important to pay attention to the existence of TCMR, because the frequency of TCMR is generally higher in AIH, which may influence the diagnosis of recurrence [195].

Genetic factors may also play roles in the recurrence of AIH. Several studies over the last two decades detected HLA-DR isotype involvement. Two initial reports suggested that HLA-DR3 positivity in recipients has a negative impact on recurrence [192], especially in HLA-DR3 negative allografts [191]. A recent study also described how mismatches on both HLA-DR alleles results in a significant risk of recurrence, especially for patients with single-agent immunosuppression. This study also showed that racial factors might play a role in developing a recurrence [196]. It is also true that the high activity of primary AIH before transplant influences the rates of recurrence. In a multivariate analysis, the degree of inflammatory activity and high IgG levels were recognized as risk factors for recurrence [197]. Information regarding recurrence rates based on the type of AIH seems to be limited [198].

Treatment strategies for recurrence are based mainly on primary AIH and consist of steroid, azathioprine, and mycophenolate mofetil. In recipients with risk factors, a certain level of immunosuppression is required, although a steroid-minimization approach is often applied in the liver transplant field. The long-term outcome of recurrence may show slight disadvantages in graft survival rates [199], but there appears to be no significant difference between non-recurrence and recurrence populations [196].

These three autoimmune liver diseases are summarized in Table 4 from the perspective of liver transplantation.

Table 4. Overall graft and patient survival and other key information in autoimmune liver diseases after liver transplantation.

\begin{tabular}{|c|c|c|c|}
\hline & Primary Biliary Cholangitis & Primary Sclerosing Cholangitis & Autoimmune Hepatitis \\
\hline $\begin{array}{l}\text { Patient Survival } \\
\text { after liver } \\
\text { transplantation }\end{array}$ & $\begin{array}{c}\text { About } 80-90 \% \text {, and } 70-80 \% \text { at } 5 \\
\text { and } 10 \text { years } \\
(86 \% \text { and } 76 \% \text { at } 5 \text { and } 10 \text { years } \\
\text { [200], } 90 \% \text { and } 79 \% \text { at } 5 \text { and } 10 \\
\text { years [169], } 80 \% \text { and } 71 \% \text { at } 5 \text { and } \\
10 \text { years }[163], 84.4 \% \text { and } 79 \% \text { at } 5 \\
\text { and } 10 \text { years [164]) }\end{array}$ & $\begin{array}{c}\text { About } 80-90 \% \text {, and } 70-80 \% \text { at } 5 \text { and } \\
10 \text { years } \\
(78 \% \text { and } 70 \% \text { at } 5 \text { and } 10 \text { years } \\
{[163], 87.4 \% \text { and } 83.2 \% \text { at } 5 \text { and }} \\
10 \text { years [164], } 89 \% \text { and } 79 \% \text { at } 5 \\
\text { and } 10 \text { years [201]) }\end{array}$ & $\begin{array}{c}\text { About } 75 \% \text { at } 5 \text { years } \\
\text { (76-78\% at } 5 \text { years [197]) }\end{array}$ \\
\hline $\begin{array}{l}\text { Patient Survival in } \\
\text { the recurrent group }\end{array}$ & $\begin{array}{l}\text { About } 95 \% \text { and } 80-90 \% \text { at } 5 \text { and } \\
10 \text { years } \\
\text { (96\% and } 83 \% \text { at } 5 \text { and } 10 \text { years } \\
\text { [200], } 88.5 \% / 10.1 \pm 4.3 \text { years } \\
\text { (follow-up period) [169]) }\end{array}$ & $\begin{array}{c}\text { About } 80 \% \text {, and } 50 \% \text { at } 5 \text { and } \\
10 \text { years } \\
(84 \% \text { and } 56 \% \text { at } 5 \text { and } \\
10 \text { years }[201])\end{array}$ & $\begin{array}{l}\text { About } 75 \% \text { at } 5 \text { years } \\
(76 \% \text { at } 5 \text { years [197]) }\end{array}$ \\
\hline Recurrence Rate & $\begin{array}{c}\text { About } 10 \% \text { and } 20-30 \% \text { at } 5 \text { and } \\
10 \text { years }(9.6 \% \text { and } 20.6 \% \text { at } 5 \text { and } \\
10 \text { years [171], } 13 \% \text { and } 29 \% \text { at } 5 \\
\text { and } 10 \text { years [200]) }\end{array}$ & $\begin{array}{c}\text { About } 10-20 \% \text { and } 10-30 \% \text { at } 5 \text { and } \\
10 \text { years }(13 \% \text { at } 5 \text { years }[202], 14.3 \% \\
\text { at } 9 \text { years [201], } 18.1 \% \text { and } 36 \% \text { at } 5 \\
\text { and } 10 \text { years [178], } 23 \% / \text { median } \\
4.6 \text { years [179]) }\end{array}$ & $\begin{array}{c}\text { About } 10-20 \% \text {, and } 30 \% \text { at } 5 \\
\text { and } 10 \text { years } \\
\text { (18\%, and } 32 \% \text { at } 5 \text { and } 10 \text { years } \\
\text { [197], } 25 \% / 15 \pm 2 \text { months } \\
\text { (follow-up period) [203]) }\end{array}$ \\
\hline
\end{tabular}


Table 4. Cont.

\begin{tabular}{|c|c|c|c|}
\hline & Primary Biliary Cholangitis & Primary Sclerosing Cholangitis & Autoimmune Hepatitis \\
\hline $\begin{array}{l}\text { Pathological vs. } \\
\text { clinical recurrence }\end{array}$ & $\begin{array}{c}\text { Pathological recurrence } \\
\text { predominant }\end{array}$ & $\begin{array}{l}\text { High clinical recurrence rates } \\
(30-70 \%)\end{array}$ & $\begin{array}{l}\text { Pathological recurrence } \\
\text { predominant }\end{array}$ \\
\hline Prophylaxis & Ursodeoxycholic acid & $\mathrm{N} / \mathrm{A}$ & $\mathrm{N} / \mathrm{A}$ \\
\hline Treatments & Ursodeoxycholic acid & $\mathrm{N} / \mathrm{A}$ & $\begin{array}{l}\text { Steroid, Azathioprine, } \\
\text { mycophenolate mofetil }\end{array}$ \\
\hline $\begin{array}{c}\text { Risk factors based } \\
\text { on donor } \\
\text { type/factors }\end{array}$ & Gender mismatch & A first degree relative donor & $\begin{array}{l}\text { HLA-DR locus mismatching, } \\
\text { recipient DR3+/donor DR3- }\end{array}$ \\
\hline
\end{tabular}

\subsection{Pancreas Transplantation}

Although the target diseases for pancreas transplantation may have a narrow range, recurrent primary DM could have a large negative impact on graft survival. Pancreas transplant is basically indicated for patients with type 1 insulin dependent DM or after total pancreatectomy. However, several studies, discussed below, showed that type 2 DM patients without significant insulin resistant can also become candidates for pancreas transplant with acceptable outcomes. In order to control primary outcomes, DM is a key for achieving excellent outcomes. In this section, we describe type $1 \mathrm{DM}$, which may recur after transplant.

\section{Type 1 Diabetes Mellitus}

Type $1 \mathrm{DM}$ can be classified as an autoimmune disease. Pancreas-islet-related autoantibodies are frequently identified. Although up to 20 or more different autoantibodies have been reported, islet cell Abs (ICA), insulin autoantibody (IAA), glutamic acid decarboxylase 65 (GAD65) antibody, insulinoma-associated protein-2 (IA-2) antibody, and zinc transporter 8 (ZnT8) autoantibody have been considered as clinically important autoantibodies [204]. ICA was originally discovered by Bottazzo et al. in 1974 [205]. Measuring ICA is the gold-standard method for diagnosing and predicting type $1 \mathrm{DM}$, primarily due to its high sensitivity and specificity. However, it is unreasonable to use this in the clinical setting, as it involves a complicated procedure. Furthermore, GAD65 and IA-2 have been identified as the mainly corresponding antigens of ICA [206]. Therefore, alternatively, anti-GAD65 and IA-2 Abs seem to be substituted clinically for ICA.

The overall rate of developing type $1 \mathrm{DM}$ after pancreas transplantation is relatively low, provided that effective immunosuppression is introduced [207]. However, as a typical example, recurrence occurred in twins or HLA-identical siblings who underwent livingrelated pancreas transplantation with minimal effects of immunosuppression [208]. These studies point to the importance of common HLA sharing and immunosuppression. The existence of HLA-DR3 and HLA-DR4 in the recipient's allele is particularly considered as a risk factor. HLA-DR allele sharing also seems to be an unfavorable factor regarding recurrence [209]. Conversely, even though conventional immunosuppression was introduced for HLA-mismatched pancreas transplantation, type $1 \mathrm{DM}$ recurrence was observed. It has been reported that autoantibody positivity is related to poor glucose tolerance, although this study did not include histologic examination and discards the possibilities of other causes [210].

Thus, it is reasonable to believe that a certain population is vulnerable in nature to the recurrence of an autoimmune disease. By employing a progression of immunosuppressive medications, the Miami group reported a reduction in the recurrence rate in type $1 \mathrm{DM}$. This effect may be due to induction therapy, such as anti-CD25 antibody or thymoglobulin, rather than maintenance immunosuppression [209]. However, the administration of 3-4 medications in combination may additionally suppress recurrence. 


\section{Feature Perspective and Concluding Remarks}

$\mathrm{ABMR}$ and a recurrence of primary disease are looming subjects that hinder the achievement of excellent long-term graft survival. It has been considered that ABMR is prominent in renal transplant rather than liver and pancreas transplants. Nevertheless, as a development of immunological assessments, the identification of ABMR in liver and pancreas transplants has become more apparent than before. Due to the fact that there seems to be common immunological reactions in these different organs, integrated approaches from different fields could accelerate the understanding of ABMR. Furthermore, knowing the nature of the primary disease would also facilitate tailoring immunosuppression to mitigate the risk of recurrence.

Lowering immunosuppression under a certain threshold could trigger the onset of these two distinctive conditions. Thus, it would be ideal to find more precise thresholds for each case by monitoring the recipients' immunological status. Regarding induction therapies, a single induction at pre-transplant or peri-transplant may be unfeasible with respect to maintaining the condition free from both $\mathrm{ABMR}$ and recurrence in the long term, because the recovery of immunity occurs over the course of post-transplant. However, more specific tolerance induction or complete remission from the primary disease could alleviate the risk of both entities or realize a better condition. ABMR and recurrence of primary diseases have their own preferences regarding donor immunological backgrounds, which would be contrary to each other. Donor selection could be arranged by estimating the advantages and disadvantages. Adjustment of these factors could result in improved outcomes in organ transplantation.

Author Contributions: Conceptualization, T.N.; writing—original draft preparation, T.N. and T.S.; writing - review and editing, T.N. and T.S.; funding acquisition, T.N. and T.S. All authors have read and agreed to the published version of the manuscript.

Funding: The APC was funded by JSPS KAKENHI Grant Number 19K18066.

Conflicts of Interest: The authors declare no conflict of interest.

\section{Abbreviations}

\begin{tabular}{|c|c|}
\hline ABMR & antibody-mediated rejection \\
\hline Abs & antibodies \\
\hline $\mathrm{AIH}$ & autoimmune hepatitis \\
\hline AMA & anti-mitochondrial antibodies \\
\hline ANCA & anti-neutrophil cytoplasmic autoantibodies \\
\hline anti-HBc Abs & anti-hepatitis B core antibodies \\
\hline $\mathrm{CNI}$ & calcineurin inhibitors \\
\hline CR & clinical recurrence \\
\hline DAA & direct-acting antivirals \\
\hline $\mathrm{DM}$ & diabetes mellitus \\
\hline dnDSA & de novo donor specific anti-HLA antibodies \\
\hline DSA & donor specific anti-HLA antibodies \\
\hline FGN & fibrillary glomerulonephritis \\
\hline FSGS & focal segmental glomerulosclerosis \\
\hline g-DSA & intra-graft DSA \\
\hline GAD65 & glutamic acid decarboxylase 65 \\
\hline GBM & anti-glomerular basement membrane \\
\hline GdIgA1 & galactose-deficient IgA1 \\
\hline HBeAg & hepatitis B e antigen \\
\hline HBsAg & hepatitis B surface antigen \\
\hline $\mathrm{HBV}$ & hepatitis B virus \\
\hline $\mathrm{HCC}$ & hepatocellular carcinoma \\
\hline $\mathrm{HCV}$ & hepatitis $C$ virus \\
\hline
\end{tabular}




$\begin{array}{ll}\text { HLA } & \text { human leukocyte antigen } \\ \text { IAA } & \text { insulin autoantibody } \\ \text { IA-2 } & \text { insulinoma-associated protein-2 } \\ \text { ICA } & \text { islet cell antibodies } \\ \text { IFTA } & \text { interstitial fibrosis and tubular atrophy } \\ \text { IgAN } & \text { IgA nephropathy } \\ \text { IVIG } & \text { intravenous immunoglobulin therapy } \\ \text { mCR } & \text { mild-to-moderate clinical recurrence } \\ \text { MELD } & \text { model for end-stage liver disease } \\ \text { MN } & \text { membranous nephropathy } \\ \text { MPGN } & \text { membranoproliferative glomerulonephritis } \\ \text { mTOR } & \text { mammalian target of rapamycin } \\ \text { PBC } & \text { primary biliary cholangitis } \\ \text { PLA2R } & \text { anti-phospholipase A2 receptor antibodies } \\ \text { PR } & \text { pathological recurrence } \\ \text { PSC } & \text { primary sclerosing cholangitis } \\ \text { RPGN } & \text { rapidly progressive glomerulonephritis } \\ \text { s-DSA } & \text { serum DSA } \\ \text { sCR } & \text { severe clinical recurrence } \\ \text { SLE } & \text { systemic lupus erythematosus } \\ \text { suPAR } & \text { soluble urokinase type plasminogen activator receptor } \\ \text { SVR } & \text { sustained virological response } \\ \text { TCMR } & \text { T cell-mediated rejection } \\ \text { THSD7A } & \text { thrombospondin type-1 domain-containing 7A antibodies } \\ \text { UDCA } & \text { ursodeoxycholic acid } \\ \text { ZnT8 } & \text { zinc transporter 8 } \\ \alpha \text { IgA } & \text { anti-GdigA1 IgG } \\ & \end{array}$

\section{References}

1. Wiebe, C.; Gibson, I.W.; Blydt-Hansen, T.D.; Karpinski, M.; Ho, J.; Storsley, L.J.; Goldberg, A.; Birk, P.E.; Rush, D.N.; Nickerson, P.W. Evolution and clinical pathologic correlations of de novo donor-specific HLA antibody post kidney transplant. Am. J. Transplant. 2012, 12, 1157-1167. [CrossRef] [PubMed]

2. Nakamura, T.; Shirouzu, T.; Nakata, K.; Yoshimura, N.; Ushigome, H. The Role of Major Histocompatibility Complex in Organ Transplantation-Donor Specific Anti-Major Histocompatibility Complex Antibodies Analysis Goes to the Next Stage. Int. J. Mol. Sci. 2019, 20, 4544. [CrossRef] [PubMed]

3. Nakamura, T.; Ushigome, H.; Watabe, K.; Imanishi, Y.; Masuda, K.; Matsuyama, T.; Harada, S.; Koshino, K.; Iida, T.; Nobori, S.; et al. Graft Immunocomplex Capture Fluorescence Analysis to Detect Donor-Specific Antibodies and HLA Antigen Complexes in the Allograft. Immunol. Investig. 2017, 46, 295-304. [CrossRef]

4. Solez, K.; Axelsen, R.A.; Benediktsson, H.; Burdick, J.F.; Cohen, A.H.; Colvin, R.B.; Croker, B.P.; Droz, D.; Dunnill, M.S.; Halloran, P.F.; et al. International standardization of criteria for the histologic diagnosis of renal allograft rejection: The Banff working classification of kidney transplant pathology. Kidney Int. 1993, 44, 411-422. [CrossRef] [PubMed]

5. $\quad$ Racusen, L.C.; Colvin, R.B.; Solez, K.; Mihatsch, M.J.; Halloran, P.F.; Campbell, P.M.; Cecka, M.J.; Cosyns, J.P.; Demetris, A.J.; Fishbein, M.C.; et al. Antibody-mediated rejection criteria-An addition to the Banff 97 classification of renal allograft rejection. Am. J. Transplant. 2003, 3, 708-714. [CrossRef] [PubMed]

6. Mannon, R.B.; Matas, A.J.; Grande, J.; Leduc, R.; Connett, J.; Kasiske, B.; Cecka, J.M.; Gaston, R.S.; Cosio, F.; Gourishankar, S.; et al. Inflammation in areas of tubular atrophy in kidney allograft biopsies: A potent predictor of allograft failure. Am. J. Transplant. 2010, 10, 2066-2073. [CrossRef]

7. Cherukuri, A.; Mehta, R.; Sharma, A.; Sood, P.; Zeevi, A.; Tevar, A.D.; Rothstein, D.M.; Hariharan, S. Post-transplant donor specific antibody is associated with poor kidney transplant outcomes only when combined with both T-cell-mediated rejection and non-adherence. Kidney Int. 2019, 96, 202-213. [CrossRef] [PubMed]

8. Devos, J.M.; Gaber, A.O.; Teeter, L.D.; Graviss, E.A.; Patel, S.J.; Land, G.A.; Moore, L.W.; Knight, R.J. Intermediate-term graft loss after renal transplantation is associated with both donor-specific antibody and acute rejection. Transplantation 2014, 97, 534-540. [CrossRef] [PubMed]

9. Heilman, R.L.; Nijim, A.; Desmarteau, Y.M.; Khamash, H.; Pando, M.J.; Smith, M.L.; Chakkera, H.A.; Huskey, J.; Valdez, R.; Reddy, K.S. De novo donor-specific human leukocyte antigen antibodies early after kidney transplantation. Transplantation 2014, 98, 1310-1315. [CrossRef] [PubMed]

10. Everly, M.J.; Rebellato, L.M.; Haisch, C.E.; Ozawa, M.; Parker, K.; Briley, K.P.; Catrou, P.G.; Bolin, P.; Kendrick, W.T.; Kendrick, S.A.; et al. Incidence and impact of de novo donor-specific alloantibody in primary renal allografts. Transplantation 2013, 95, 410-417. [CrossRef] [PubMed] 
11. Wan, S.S.; Chadban, S.J.; Watson, N.; Wyburn, K. Development and outcomes of de novo donor-specific antibodies in low, moderate, and high immunological risk kidney transplant recipients. Am. J. Transplant. 2020, 20, 1351-1364. [CrossRef] [PubMed]

12. De Fijter, J.W.; Holdaas, H.; Øyen, O.; Sanders, J.S.; Sundar, S.; Bemelman, F.J.; Sommerer, C.; Pascual, J.; Avihingsanon, Y.; Pongskul, C.; et al. Early Conversion From Calcineurin Inhibitor- to Everolimus-Based Therapy Following Kidney Transplantation: Results of the Randomized ELEVATE Trial. Am. J. Transplant. 2017, 17, 1853-1867. [CrossRef] [PubMed]

13. Filler, G.; Todorova, E.K.; Bax, K.; Alvarez-Elías, A.C.; Huang, S.H.; Kobrzynski, M.C. Minimum mycophenolic acid levels are associated with donor-specific antibody formation. Pediatr. Transplant. 2016, 20, 34-38. [CrossRef]

14. Solomon, S.; Colovai, A.; Del Rio, M.; Hayde, N. Tacrolimus variability is associated with de novo donor-specific antibody development in pediatric renal transplant recipients. Pediatr. Nephrol. 2020, 35, 261-270. [CrossRef] [PubMed]

15. Croze, L.E.; Tetaz, R.; Roustit, M.; Malvezzi, P.; Janbon, B.; Jouve, T.; Pinel, N.; Masson, D.; Quesada, J.L.; Bayle, F.; et al. Conversion to mammalian target of rapamycin inhibitors increases risk of de novo donor-specific antibodies. Transpl. Int. 2014, 27, 775-783. [CrossRef]

16. Bertrand, D.; Gatault, P.; Jauréguy, M.; Garrouste, C.; Sayegh, J.; Bouvier, N.; Caillard, S.; Lanfranco, L.; Galinier, A.; Laurent, C.; et al. Protocol Biopsies in Patients With Subclinical De Novo Donor-specific Antibodies After Kidney Transplantation: A Multicentric Study. Transplantation 2020, 104, 1726-1737. [CrossRef] [PubMed]

17. Delgado, J.C.; Fuller, A.; Ozawa, M.; Smith, L.; Terasaki, P.I.; Shihab, F.S.; Eckels, D.D. No occurrence of de novo HLA antibodies in patients with early corticosteroid withdrawal in a 5-year prospective randomized study. Transplantation 2009, 87, 546-548. [CrossRef] [PubMed]

18. Nakamura, T.; Ushigome, H.; Shirouzu, T.; Yoshimura, N. Donor Specific anti-HLA Antibodies in Organ Transplantation-Transition from Serum DSA to Intra-Graft DSA, November 5th 2018 ed.; Mahdi, B.M., Ed.; Intech: London, UK, 2019; pp. $19-41$.

19. Eskandary, F.; Regele, H.; Baumann, L.; Bond, G.; Kozakowski, N.; Wahrmann, M.; Hidalgo, L.G.; Haslacher, H.; Kaltenecker, C.C.; Aretin, M.B.; et al. A Randomized Trial of Bortezomib in Late Antibody-Mediated Kidney Transplant Rejection. J. Am. Soc. Nephrol. JASN 2018, 29, 591-605. [CrossRef] [PubMed]

20. Kulkarni, S.; Kirkiles-Smith, N.C.; Deng, Y.H.; Formica, R.N.; Moeckel, G.; Broecker, V.; Bow, L.; Tomlin, R.; Pober, J.S. Eculizumab Therapy for Chronic Antibody-Mediated Injury in Kidney Transplant Recipients: A Pilot Randomized Controlled Trial. Am. J. Transplant 2017, 17, 682-691. [CrossRef]

21. Choi, J.; Aubert, O.; Vo, A.; Loupy, A.; Haas, M.; Puliyanda, D.; Kim, I.; Louie, S.; Kang, A.; Peng, A.; et al. Assessment of Tocilizumab (Anti-Interleukin-6 Receptor Monoclonal) as a Potential Treatment for Chronic Antibody-Mediated Rejection and Transplant Glomerulopathy in HLA-Sensitized Renal Allograft Recipients. Am. J. Transplant. 2017, 17, 2381-2389. [CrossRef] [PubMed]

22. Shin, B.H.; Everly, M.J.; Zhang, H.; Choi, J.; Vo, A.; Zhang, X.; Huang, E.; Jordan, S.C.; Toyoda, M. Impact of Tocilizumab (Anti-IL6R) Treatment on Immunoglobulins and Anti-HLA Antibodies in Kidney Transplant Patients With Chronic Antibody-mediated Rejection. Transplantation 2020, 104, 856-863. [CrossRef]

23. Doberer, K.; Duerr, M.; Halloran, P.F.; Eskandary, F.; Budde, K.; Regele, H.; Reeve, J.; Borski, A.; Kozakowski, N.; ReindlSchwaighofer, R.; et al. A Randomized Clinical Trial of Anti-IL-6 Antibody Clazakizumab in Late Antibody-Mediated Kidney Transplant Rejection. J. Am. Soc. Nephrol. JASN 2021, 32, 708-722. [CrossRef] [PubMed]

24. Bray, R.A.; Gebel, H.M.; Townsend, R.; Roberts, M.E.; Polinsky, M.; Yang, L.; Meier-Kriesche, H.U.; Larsen, C.P. De novo donor-specific antibodies in belatacept-treated vs cyclosporine-treated kidney-transplant recipients: Post hoc analyses of the randomized phase III BENEFIT and BENEFIT-EXT studies. Am. J. Transplant. 2018, 18, 1783-1789. [CrossRef] [PubMed]

25. Vandevoorde, K.; Ducreux, S.; Bosch, A.; Guillaud, O.; Hervieu, V.; Chambon-Augoyard, C.; Poinsot, D.; André, P.; Scoazec, J.Y.; Robinson, P.; et al. Prevalence, Risk Factors, and Impact of Donor-Specific Alloantibodies After Adult Liver Transplantation. Liver Transplant. 2018, 24, 1091-1100. [CrossRef] [PubMed]

26. Demetris, A.J.; Bellamy, C.; Hubscher, S.G.; O’Leary, J.; Randhawa, P.S.; Feng, S.; Neil, D.; Colvin, R.B.; McCaughan, G.; Fung, J.J.; et al. 2016 Comprehensive Update of the Banff Working Group on Liver Allograft Pathology: Introduction of Antibody-Mediated Rejection. Am. J. Transplant. 2016, 16, 2816-2835. [CrossRef]

27. Nakamura, T.; Shirouzu, T.; Kawai, S.; Sugimoto, R.; Harada, S.; Yoshikawa, M.; Nobori, S.; Ushigome, H. Intra-Liver Allograft C3d-Binding Donor Specific anti-HLA Antibodies Predict Rejection after Liver Transplantation. Transplant. Proc. 2022, in press.

28. Gugenheim, J.; Le Thai, B.; Rouger, P.; Gigou, M.; Gane, P.; Vial, M.C.; Charpentier, B.; Reynes, M.; Bismuth, H. Relationship between the liver and lymphocytotoxic alloantibodies in inbred rats. Specific absorption by nonparenchymal liver cells. Transplantation 1988, 45, 474-478. [CrossRef] [PubMed]

29. Chauhan, B.; Phelan, D.L.; Marsh, J.W.; Mohanakumar, T. Characterization of antiidiotypic antibodies to donor HLA that develop after liver transplantation. Transplantation 1993, 56, 443-448. [CrossRef]

30. Astarcioglu, I.; Cursio, R.; Reynes, M.; Gugenheim, J. Increased risk of antibody-mediated rejection of reduced-size liver allografts. J. Surg. Res. 1999, 87, 258-262. [CrossRef] [PubMed]

31. Liu, X.; Xu, J.; Brenner, D.A.; Kisseleva, T. Reversibility of Liver Fibrosis and Inactivation of Fibrogenic Myofibroblasts. Curr. Pathobiol. Rep. 2013, 1, 209-214. [CrossRef] [PubMed]

32. Feng, S.; Bucuvalas, J.C.; Mazariegos, G.V.; Magee, J.C.; Sanchez-Fueyo, A.; Spain, K.M.; Lesniak, A.; Kanaparthi, S.; Perito, E.; Venkat, V.L.; et al. Efficacy and Safety of Immunosuppression Withdrawal in Pediatric Liver Transplant Recipients: Moving Toward Personalized Management. Hepatology 2021, 73, 1985-2004. [CrossRef] [PubMed] 
33. Schluckebier, D.; Cousin, V.L.; Petit, L.M.; Belli, D.; Wildhaber, B.; Rougemont, A.L.; Villard, J.; Ferrari-Lacraz, S.; McLin, V.A. Preformed and de novo DSA are associated with T-cell-mediated rejection in pediatric liver transplant recipients requiring clinically indicated liver biopsy. Pediatr. Transplant. 2020, 24, e13611. [CrossRef] [PubMed]

34. Miyagawa-Hayashino, A.; Yoshizawa, A.; Uchida, Y.; Egawa, H.; Yurugi, K.; Masuda, S.; Minamiguchi, S.; Maekawa, T.; Uemoto, S.; Haga, H. Progressive graft fibrosis and donor-specific human leukocyte antigen antibodies in pediatric late liver allografts. Liver Transplant. 2012, 18, 1333-1342. [CrossRef] [PubMed]

35. Del Bello, A.; Congy-Jolivet, N.; Muscari, F.; Lavayssière, L.; Esposito, L.; Cardeau-Desangles, I.; Guitard, J.; Dörr, G.; Suc, B.; Duffas, J.P.; et al. Prevalence, incidence and risk factors for donor-specific anti-HLA antibodies in maintenance liver transplant patients. Am. J. Transplant. 2014, 14, 867-875. [CrossRef] [PubMed]

36. Höfer, A.; Jonigk, D.; Hartleben, B.; Verboom, M.; Hallensleben, M.; Hübscher, S.G.; Manns, M.P.; Jaeckel, E.; Taubert, R. DSA Are Associated With More Graft Injury, More Fibrosis, and Upregulation of Rejection-associated Transcripts in Subclinical Rejection. Transplantation 2020, 104, 551-561. [CrossRef] [PubMed]

37. Kaneku, H.; O’Leary, J.G.; Banuelos, N.; Jennings, L.W.; Susskind, B.M.; Klintmalm, G.B.; Terasaki, P.I. De novo donor-specific HLA antibodies decrease patient and graft survival in liver transplant recipients. Am. J. Transplant. 2013, 13, 1541-1548. [CrossRef] [PubMed]

38. Del Bello, A.; Congy-Jolivet, N.; Danjoux, M.; Muscari, F.; Lavayssière, L.; Esposito, L.; Cardeau-Desangles, I.; Guitard, J.; Dörr, G.; Milongo, D.; et al. De novo donor-specific anti-HLA antibodies mediated rejection in liver-transplant patients. Transpl. Int. 2015, 28, 1371-1382. [CrossRef] [PubMed]

39. Sakamoto, S.; Akamatsu, N.; Hasegawa, K.; Ohdan, H.; Nakagawa, K.; Egawa, H. The efficacy of rituximab treatment for antibody-mediated rejection in liver transplantation: A retrospective Japanese nationwide study. Hepatol. Res. 2021, 51, 990-999. [CrossRef]

40. De Kort, H.; Munivenkatappa, R.B.; Berger, S.P.; Eikmans, M.; van der Wal, A.; de Koning, E.J.; van Kooten, C.; de Heer, E.; Barth, R.N.; Bruijn, J.A.; et al. Pancreas allograft biopsies with positive c4d staining and anti-donor antibodies related to worse outcome for patients. Am. J. Transpl. 2010, 10, 1660-1667. [CrossRef] [PubMed]

41. De Kort, H.; Mallat, M.J.; van Kooten, C.; de Heer, E.; Brand-Schaaf, S.H.; van der Wal, A.M.; Roufosse, C.; Roelen, D.L.; Bruijn, J.A.; Claas, F.H.; et al. Diagnosis of early pancreas graft failure via antibody-mediated rejection: Single-center experience with 256 pancreas transplantations. Am. J. Transpl. 2014, 14, 936-942. [CrossRef]

42. Cantarovich, D.; De Amicis, S.; Akl, A.; Devys, A.; Vistoli, F.; Karam, G.; Soulillou, J.P. Posttransplant donor-specific anti-HLA antibodies negatively impact pancreas transplantation outcome. Am. J. Transpl. 2011, 11, 2737-2746. [CrossRef] [PubMed]

43. Parajuli, S.; Alagusundaramoorthy, S.; Aziz, F.; Garg, N.; Redfield, R.R.; Sollinger, H.; Kaufman, D.; Djamali, A.; Odorico, J.; Mandelbrot, D. Outcomes of Pancreas Transplant Recipients with De Novo Donor-specific Antibodies. Transplantation 2019, 103, 435-440. [CrossRef]

44. Ladowski, J.M.; Mullins, H.; Romine, M.; Kloda, D.; Young, C.; Hauptfeld-Dolejsek, V.; Houp, J.; Locke, J. Eplet mismatch scores and de novo donor-specific antibody development in simultaneous pancreas-kidney transplantation. Hum. Immunol. 2021, 82, 139-146. [CrossRef] [PubMed]

45. Chaigne, B.; Geneugelijk, K.; Bédat, B.; Ahmed, M.A.; Hönger, G.; De Seigneux, S.; Demuylder-Mischler, S.; Berney, T.; Spierings, E.; Ferrari-Lacraz, S.; et al. Immunogenicity of Anti-HLA Antibodies in Pancreas and Islet Transplantation. Cell Transpl. 2016, 25, 2041-2050. [CrossRef] [PubMed]

46. Uva, P.D.; Quevedo, A.; Roses, J.; Toniolo, M.F.; Pilotti, R.; Chuluyan, E.; Casadei, D.H. Anti-Hla donor-specific antibody monitoring in pancreas transplantation: Role of protocol biopsies. Clin. Transpl. 2020, 34, e13998. [CrossRef] [PubMed]

47. Drachenberg, C.B.; Torrealba, J.R.; Nankivell, B.J.; Rangel, E.B.; Bajema, I.M.; Kim, D.U.; Arend, L.; Bracamonte, E.R.; Bromberg, J.S.; Bruijn, J.A.; et al. Guidelines for the diagnosis of antibody-mediated rejection in pancreas allografts-updated Banff grading schema. Am. J. Transpl. 2011, 11, 1792-1802. [CrossRef] [PubMed]

48. Gunther Brockmann, J.; Butt, A.; AlHussaini, H.F.; AlMana, H.; AlSaad, K.; Al-Awwami, M.; Clemens Broering, D.; Ali, T. Protocol Duodenal Graft Biopsies Aid Pancreas Graft Surveillance. Transplantation 2019, 103, 622-629. [CrossRef]

49. Moreso, F.; Crespo, M.; Ruiz, J.C.; Torres, A.; Gutierrez-Dalmau, A.; Osuna, A.; Perello, M.; Pascual, J.; Torres, I.B.; RedondoPachon, D.; et al. Treatment of chronic antibody mediated rejection with intravenous immunoglobulins and rituximab: A multicenter, prospective, randomized, double-blind clinical trial. Am. J. Transplant. 2018, 18, 927-935. [CrossRef]

50. Redfield, R.R.; Ellis, T.M.; Zhong, W.; Scalea, J.R.; Zens, T.J.; Mandelbrot, D.; Muth, B.L.; Panzer, S.; Samaniego, M.; Kaufman, D.B.; et al. Current outcomes of chronic active antibody mediated rejection-A large single center retrospective review using the updated BANFF 2013 criteria. Hum. Immunol. 2016, 77, 346-352. [CrossRef]

51. Guerra, M.R.; Naini, B.V.; Scapa, J.V.; Reed, E.F.; Busuttil, R.W.; Cheng, E.Y.; Farmer, D.G.; Vargas, J.H.; Venick, R.S.; McDiarmid, S.V.; et al. Obliterative portal venopathy: A histopathologic finding associated with chronic antibody-mediated rejection in pediatric liver allografts. Pediatr. Transplant. 2018, 22, e13124. [CrossRef] [PubMed]

52. Kawabe, M.; Yamamoto, I.; Komatsuzaki, Y.; Yamakawa, T.; Katsumata, H.; Katsuma, A.; Mafune, A.; Nakada, Y.; Kobayashi, A.; Tanno, Y.; et al. Recurrence and graft loss after renal transplantation in adults with IgA vasculitis. Clin. Exp. Nephrol. 2017, 21, 714-720. [CrossRef]

53. Ponticelli, C.; Traversi, L.; Feliciani, A.; Cesana, B.M.; Banfi, G.; Tarantino, A. Kidney transplantation in patients with IgA mesangial glomerulonephritis. Kidney Int. 2001, 60, 1948-1954. [CrossRef] 
54. Di Vico, M.C.; Messina, M.; Fop, F.; Barreca, A.; Segoloni, G.P.; Biancone, L. Recurrent IgA nephropathy after renal transplantation and steroid withdrawal. Clin. Transplant. 2018, 32, e13207. [CrossRef] [PubMed]

55. Mousson, C.; Charon-Barra, C.; Funes de la Vega, M.; Tanter, Y.; Justrabo, E.; Martin, L.; Rifle, G. Recurrence of IgA nephropathy with crescents in kidney transplants. Transplant. Proc. 2007, 39, 2595-2596. [CrossRef]

56. Clayton, P.; McDonald, S.; Chadban, S. Steroids and recurrent IgA nephropathy after kidney transplantation. Am. J. Transplant. 2011, 11, 1645-1649. [CrossRef] [PubMed]

57. Rodas, L.M.; Ruiz-Ortiz, E.; Garcia-Herrera, A.; Pereira, A.; Blasco, M.; Ventura-Aguiar, P.; Viñas Gomis, O.; Egri, N.; De Sousa, E.; Palou, E.; et al. IgA Nephropathy Recurrence after Kidney Transplantation: Role of Recipient Age and Human Leukocyte Antigen-B Mismatch. Am. J. Nephrol. 2020, 51, 357-365. [CrossRef]

58. Suzuki, H.; Fan, R.; Zhang, Z.; Brown, R.; Hall, S.; Julian, B.A.; Chatham, W.W.; Suzuki, Y.; Wyatt, R.J.; Moldoveanu, Z.; et al. Aberrantly glycosylated IgA1 in IgA nephropathy patients is recognized by IgG antibodies with restricted heterogeneity. J. Clin. Investig. 2009, 119, 1668-1677. [CrossRef] [PubMed]

59. Suzuki, Y.; Matsuzaki, K.; Suzuki, H.; Okazaki, K.; Yanagawa, H.; Ieiri, N.; Sato, M.; Sato, T.; Taguma, Y.; Matsuoka, J.; et al. Serum levels of galactose-deficient immunoglobulin (Ig) A1 and related immune complex are associated with disease activity of IgA nephropathy. Clin. Exp. Nephrol. 2014, 18, 770-777. [CrossRef]

60. Rizk, D.V.; Saha, M.K.; Hall, S.; Novak, L.; Brown, R.; Huang, Z.Q.; Fatima, H.; Julian, B.A.; Novak, J. Glomerular Immunodeposits of Patients with IgA Nephropathy Are Enriched for IgG Autoantibodies Specific for Galactose-Deficient IgA1. J. Am. Soc. Nephrol. JASN 2019, 30, 2017-2026. [CrossRef] [PubMed]

61. Berthoux, F.; Suzuki, H.; Mohey, H.; Maillard, N.; Mariat, C.; Novak, J.; Julian, B.A. Prognostic Value of Serum Biomarkers of Autoimmunity for Recurrence of IgA Nephropathy after Kidney Transplantation. J. Am. Soc. Nephrol. JASN 2017, 28, 1943-1950. [CrossRef]

62. Nakamura, T.; Shirouzu, T.; Harada, S.; Sugimoto, R.; Nobori, S.; Yoshikawa, M.; Ushigome, H.; Kawai, S. The Abundance of Anti-Galactose-deficient IgA1 Autoantibodies Results in Glomerular Deposition and IgA Nephropathy Recurrence after Renal Transplantation. Transplantation 2021, 105. in press. [CrossRef]

63. Kawabe, M.; Yamamoto, I.; Yamakawa, T.; Katsumata, H.; Isaka, N.; Katsuma, A.; Nakada, Y.; Kobayashi, A.; Koike, K.; Ueda, H.; et al. Association Between Galactose-Deficient IgA1 Derived From the Tonsils and Recurrence of IgA Nephropathy in Patients Who Underwent Kidney Transplantation. Front. Immunol. 2020, 11, 2068. [CrossRef]

64. Okumi, M.; Okada, D.; Unagami, K.; Kakuta, Y.; Iizuka, J.; Takagi, T.; Shirakawa, H.; Omoto, K.; Ishida, H.; Tanabe, K. Higher immunoglobulin A nephropathy recurrence in related-donor kidney transplants: The Japan Academic Consortium of Kidney Transplantation study. Int. J. Urol. 2019, 26, 903-909. [CrossRef]

65. Messina, M.; di Vico, M.C.; Ariaudo, C.; Mazzucco, G.; Fop, F.; Segoloni, G.P.; Biancone, L. Treatment protocol with pulse and oral steroids for IgA Nephropathy after kidney transplantation. J. Nephrol. 2016, 29, 575-583. [CrossRef]

66. Jiang, S.H.; Kennard, A.L.; Walters, G.D. Recurrent glomerulonephritis following renal transplantation and impact on graft survival. BMC Nephrol. 2018, 19, 344. [CrossRef]

67. Alasfar, S.; Matar, D.; Montgomery, R.A.; Desai, N.; Lonze, B.; Vujjini, V.; Estrella, M.M.; Manllo Dieck, J.; Khneizer, G.; Sever, S.; et al. Rituximab and Therapeutic Plasma Exchange in Recurrent Focal Segmental Glomerulosclerosis Postkidney Transplantation. Transplantation 2018, 102, e115-e120. [CrossRef]

68. Francis, A.; Trnka, P.; McTaggart, S.J. Long-Term Outcome of Kidney Transplantation in Recipients with Focal Segmental Glomerulosclerosis. Clin. J. Am. Soc. Nephrol. CJASN 2016, 11, 2041-2046. [CrossRef]

69. Uffing, A.; Pérez-Sáez, M.J.; Mazzali, M.; Manfro, R.C.; Bauer, A.C.; de Sottomaior Drumond, F.; O’Shaughnessy, M.M.; Cheng, X.S.; Chin, K.K.; Ventura, C.G.; et al. Recurrence of FSGS after Kidney Transplantation in Adults. Clin. J. Am. Soc. Nephrol. CJASN 2020, 15, 247-256. [CrossRef]

70. Allen, P.J.; Chadban, S.J.; Craig, J.C.; Lim, W.H.; Allen, R.D.M.; Clayton, P.A.; Teixeira-Pinto, A.; Wong, G. Recurrent glomerulonephritis after kidney transplantation: Risk factors and allograft outcomes. Kidney Int. 2017, 92, 461-469. [CrossRef]

71. Gallon, L.; Leventhal, J.; Skaro, A.; Kanwar, Y.; Alvarado, A. Resolution of recurrent focal segmental glomerulosclerosis after retransplantation. N. Engl. J. Med. 2012, 366, 1648-1649. [CrossRef]

72. Sharma, M.; Sharma, R.; Reddy, S.R.; McCarthy, E.T.; Savin, V.J. Proteinuria after injection of human focal segmental glomerulosclerosis factor. Transplantation 2002, 73, 366-372. [CrossRef] [PubMed]

73. Wei, C.; El Hindi, S.; Li, J.; Fornoni, A.; Goes, N.; Sageshima, J.; Maiguel, D.; Karumanchi, S.A.; Yap, H.K.; Saleem, M.; et al. Circulating urokinase receptor as a cause of focal segmental glomerulosclerosis. Nat. Med. 2011, 17, 952-960. [CrossRef]

74. Alachkar, N.; Wei, C.; Arend, L.J.; Jackson, A.M.; Racusen, L.C.; Fornoni, A.; Burke, G.; Rabb, H.; Kakkad, K.; Reiser, J.; et al. Podocyte effacement closely links to suPAR levels at time of posttransplantation focal segmental glomerulosclerosis occurrence and improves with therapy. Transplantation 2013, 96, 649-656. [CrossRef]

75. Verghese, P.S.; Rheault, M.N.; Jackson, S.; Matas, A.J.; Chinnakotla, S.; Chavers, B. The effect of peri-transplant plasmapheresis in the prevention of recurrent FSGS. Pediatr. Transplant. 2018, 22, e13154. [CrossRef]

76. Kennard, A.L.; Jiang, S.H.; Walters, G.D. Increased glomerulonephritis recurrence after living related donation. BMC Nephrol. 2017, 18, 25. [CrossRef] 
77. Lanaret, C.; Anglicheau, D.; Audard, V.; Büchler, M.; Caillard, S.; Couzi, L.; Malvezzi, P.; Mesnard, L.; Bertrand, D.; Martinez, F.; et al. Rituximab for recurrence of primary focal segmental glomerulosclerosis after kidney transplantation: Results of a nationwide study. Am. J. Transplant. 2021, 21, 3021-3033. [CrossRef] [PubMed]

78. Staeck, O.; Slowinski, T.; Lieker, I.; Wu, K.; Rudolph, B.; Schmidt, D.; Brakemeier, S.; Neumayer, H.H.; Wei, C.; Reiser, J.; et al. Recurrent Primary Focal Segmental Glomerulosclerosis Managed With Intensified Plasma Exchange and Concomitant Monitoring of Soluble Urokinase-Type Plasminogen Activator Receptor-Mediated Podocyte $\beta 3$-integrin Activation. Transplantation 2015, 99 , 2593-2597. [CrossRef]

79. Sethi, S.; Nester, C.M.; Smith, R.J. Membranoproliferative glomerulonephritis and C3 glomerulopathy: Resolving the confusion. Kidney Int. 2012, 81, 434-441. [CrossRef]

80. Fakhouri, F.; Le Quintrec, M.; Frémeaux-Bacchi, V. Practical management of C3 glomerulopathy and Ig-mediated MPGN: Facts and uncertainties. Kidney Int. 2020, 98, 1135-1148. [CrossRef]

81. Sethi, S.; Fervenza, F.C. Membranoproliferative glomerulonephritis: Pathogenetic heterogeneity and proposal for a new classification. Semin. Nephrol. 2011, 31, 341-348. [CrossRef]

82. Regunathan-Shenk, R.; Avasare, R.S.; Ahn, W.; Canetta, P.A.; Cohen, D.J.; Appel, G.B.; Bomback, A.S. Kidney Transplantation in C3 Glomerulopathy: A Case Series. Am. J. Kidney Dis. 2019, 73, 316-323. [CrossRef]

83. Green, H.; Rahamimov, R.; Rozen-Zvi, B.; Pertzov, B.; Tobar, A.; Lichtenberg, S.; Gafter, U.; Mor, E. Recurrent membranoproliferative glomerulonephritis type I after kidney transplantation: A 17-year single-center experience. Transplantation 2015, 99, 1172-1177. [CrossRef]

84. Gonzalez Suarez, M.L.; Thongprayoon, C.; Hansrivijit, P.; Kovvuru, K.; Kanduri, S.R.; Aeddula, N.R.; Pivovarova, A.I.; Chewcharat, A.; Bathini, T.; Mao, M.A.; et al. Treatment of C3 Glomerulopathy in Adult Kidney Transplant Recipients: A Systematic Review. Med. Sci. 2020, 8, 44. [CrossRef] [PubMed]

85. Moszczuk, B.; Kiryluk, K.; Pączek, L.; Mucha, K. Membranous Nephropathy: From Research Bench to Personalized Care. J. Clin. Med. 2021, 10, 1205. [CrossRef]

86. Beck, L.H., Jr.; Bonegio, R.G.; Lambeau, G.; Beck, D.M.; Powell, D.W.; Cummins, T.D.; Klein, J.B.; Salant, D.J. M-type phospholipase A2 receptor as target antigen in idiopathic membranous nephropathy. N. Engl. J. Med. 2009, 361, 11-21. [CrossRef]

87. Tomas, N.M.; Beck, L.H., Jr.; Meyer-Schwesinger, C.; Seitz-Polski, B.; Ma, H.; Zahner, G.; Dolla, G.; Hoxha, E.; Helmchen, U.; Dabert-Gay, A.S.; et al. Thrombospondin type-1 domain-containing 7A in idiopathic membranous nephropathy. N. Engl. J. Med. 2014, 371, 2277-2287. [CrossRef]

88. Sprangers, B.; Lefkowitz, G.I.; Cohen, S.D.; Stokes, M.B.; Valeri, A.; Appel, G.B.; Kunis, C.L. Beneficial effect of rituximab in the treatment of recurrent idiopathic membranous nephropathy after kidney transplantation. Clin. J. Am. Soc. Nephrol. CJASN 2010, 5, 790-797. [CrossRef]

89. Kattah, A.; Ayalon, R.; Beck, L.H., Jr.; Sethi, S.; Sandor, D.G.; Cosio, F.G.; Gandhi, M.J.; Lorenz, E.C.; Salant, D.J.; Fervenza, F.C. Anti-phospholipase $\mathrm{A}_{2}$ receptor antibodies in recurrent membranous nephropathy. Am. J. Transplant. 2015, 15, 1349-1359. [CrossRef] [PubMed]

90. Tomas, N.M.; Hoxha, E.; Reinicke, A.T.; Fester, L.; Helmchen, U.; Gerth, J.; Bachmann, F.; Budde, K.; Koch-Nolte, F.; Zahner, G.; et al. Autoantibodies against thrombospondin type 1 domain-containing 7A induce membranous nephropathy. J. Clin. Investig. 2016, 126, 2519-2532. [CrossRef] [PubMed]

91. Batal, I.; Vasilescu, E.R.; Dadhania, D.M.; Adel, A.A.; Husain, S.A.; Avasare, R.; Serban, G.; Santoriello, D.; Khairallah, P.; Patel, A.; et al. Association of HLA Typing and Alloimmunity With Posttransplantation Membranous Nephropathy: A Multicenter Case Series. Am. J. Kidney Dis. 2020, 76, 374-383. [CrossRef] [PubMed]

92. Hickson, L.J.; Gera, M.; Amer, H.; Iqbal, C.W.; Moore, T.B.; Milliner, D.S.; Cosio, F.G.; Larson, T.S.; Stegall, M.D.; Ishitani, M.B.; et al. Kidney transplantation for primary focal segmental glomerulosclerosis: Outcomes and response to therapy for recurrence. Transplantation 2009, 87, 1232-1239. [CrossRef]

93. Yang, W.L.; Bose, B.; Zhang, L.; McStea, M.; Cho, Y.; Fahim, M.; Hawley, C.M.; Pascoe, E.M.; Johnson, D.W. Long-term outcomes of patients with end-stage kidney disease due to membranous nephropathy: A cohort study using the Australia and New Zealand Dialysis and Transplant Registry. PLoS ONE 2019, 14, e0221531. [CrossRef] [PubMed]

94. Choy, B.Y.; Chan, T.M.; Lo, S.K.; Lo, W.K.; Lai, K.N. Renal transplantation in patients with primary immunoglobulin A nephropathy. Nephrol. Dial. Transplant. 2003, 18, 2399-2404. [CrossRef]

95. Tamirou, F.; Houssiau, F.A. Management of Lupus Nephritis. J. Clin. Med. 2021, 10, 670. [CrossRef] [PubMed]

96. Seligman, V.A.; Lum, R.F.; Olson, J.L.; Li, H.; Criswell, L.A. Demographic differences in the development of lupus nephritis: A retrospective analysis. Am. J. Med. 2002, 112, 726-729. [CrossRef]

97. Hoffman, I.E.; Peene, I.; Meheus, L.; Huizinga, T.W.; Cebecauer, L.; Isenberg, D.; De Bosschere, K.; Hulstaert, F.; Veys, E.M.; De Keyser, F. Specific antinuclear antibodies are associated with clinical features in systemic lupus erythematosus. Ann. Rheum. Dis. 2004, 63, 1155-1158. [CrossRef]

98. Contreras, G.; Mattiazzi, A.; Guerra, G.; Ortega, L.M.; Tozman, E.C.; Li, H.; Tamariz, L.; Carvalho, C.; Kupin, W.; Ladino, M.; et al. Recurrence of lupus nephritis after kidney transplantation. J. Am. Soc. Nephrol. JASN 2010, 21, 1200-1207. [CrossRef] [PubMed]

99. Bunnapradist, S.; Chung, P.; Peng, A.; Hong, A.; Chung, P.; Lee, B.; Fukami, S.; Takemoto, S.K.; Singh, A.K. Outcomes of renal transplantation for recipients with lupus nephritis: Analysis of the Organ Procurement and Transplantation Network database. Transplantation 2006, 82, 612-618. [CrossRef] 
100. Deegens, J.K.; Artz, M.A.; Hoitsma, A.J.; Wetzels, J.F. Outcome of renal transplantation in patients with systemic lupus erythematosus. Transpl. Int. 2003, 16, 411-418. [CrossRef]

101. Goral, S.; Ynares, C.; Shappell, S.B.; Snyder, S.; Feurer, I.D.; Kazancioglu, R.; Fogo, A.B.; Helderman, J.H. Recurrent lupus nephritis in renal transplant recipients revisited: It is not rare. Transplantation 2003, 75, 651-656. [CrossRef]

102. Ponticelli, C.; Moroni, G. Renal transplantation in lupus nephritis. Lupus 2005, 14, 95-98. [CrossRef]

103. Rovin, B.H.; Furie, R.; Latinis, K.; Looney, R.J.; Fervenza, F.C.; Sanchez-Guerrero, J.; Maciuca, R.; Zhang, D.; Garg, J.P.; Brunetta, P.; et al. Efficacy and safety of rituximab in patients with active proliferative lupus nephritis: The Lupus Nephritis Assessment with Rituximab study. Arthritis Rheum. 2012, 64, 1215-1226. [CrossRef] [PubMed]

104. Moroni, G.; Ponticelli, C. Rapidly progressive crescentic glomerulonephritis: Early treatment is a must. Autoimmun. Rev. 2014, 13, 723-729. [CrossRef] [PubMed]

105. Göçeroğlu, A.; Rahmattulla, C.; Berden, A.E.; Reinders, M.E.; Wolterbeek, R.; Steenbergen, E.J.; Hilbrands, L.B.; Noorlander, I.; Berger, S.P.; Peutz-Kootstra, C.J.; et al. The Dutch Transplantation in Vasculitis (DUTRAVAS) Study: Outcome of Renal Transplantation in Antineutrophil Cytoplasmic Antibody-associated Glomerulonephritis. Transplantation 2016, 100, 916-924. [CrossRef] [PubMed]

106. Little, M.A.; Hassan, B.; Jacques, S.; Game, D.; Salisbury, E.; Courtney, A.E.; Brown, C.; Salama, A.D.; Harper, L. Renal transplantation in systemic vasculitis: When is it safe? Nephrol. Dial. Transplant. 2009, 24, 3219-3225. [CrossRef]

107. Nachman, P.H.; Segelmark, M.; Westman, K.; Hogan, S.L.; Satterly, K.K.; Jennette, J.C.; Falk, R. Recurrent ANCA-associated small vessel vasculitis after transplantation: A pooled analysis. Kidney Int. 1999, 56, 1544-1550. [CrossRef] [PubMed]

108. Kluth, D.C.; Rees, A.J. Anti-glomerular basement membrane disease. J. Am. Soc. Nephrol. JASN 1999, 10, 2446-2453. [CrossRef]

109. Singh, T.; Kharadjian, T.B.; Astor, B.C.; Panzer, S.E. Long-term outcomes in kidney transplant recipients with end-stage kidney disease due to anti-glomerular basement membrane disease. Clin. Transplant. 2021, 35, e14179. [CrossRef]

110. Tang, W.; McDonald, S.P.; Hawley, C.M.; Badve, S.V.; Boudville, N.C.; Brown, F.G.; Clayton, P.A.; Campbell, S.B.; de Zoysa, J.R.; Johnson, D.W. Anti-glomerular basement membrane antibody disease is an uncommon cause of end-stage renal disease. Kidney Int. 2013, 83, 503-510. [CrossRef]

111. Netzer, K.O.; Merkel, F.; Weber, M. Goodpasture syndrome and end-stage renal failure-to transplant or not to transplant? Nephrol. Dial. Transplant. 1998, 13, 1346-1348. [CrossRef]

112. Lochhead, K.M.; Pirsch, J.D.; D’Alessandro, A.M.; Knechtle, S.J.; Kalayoglu, M.; Sollinger, H.W.; Belzer, F.O. Risk factors for renal allograft loss in patients with systemic lupus erythematosus. Kidney Int. 1996, 49, 512-517. [CrossRef] [PubMed]

113. Jennette, J.C.; Nachman, P.H. ANCA Glomerulonephritis and Vasculitis. Clin. J. Am. Soc. Nephrol. CJASN 2017, $12,1680-1691$. [CrossRef]

114. Ronco, P.M.; Aucouturier, P. The molecular bases of plasma cell dyscrasia-related renal diseases. Nephrol. Dial. Transplant. 1999, 14 (Suppl. S1), 4-8. [CrossRef]

115. Röcken, C.; Sletten, K. Amyloid in surgical pathology. Virchows Arch. 2003, 443, 3-16. [CrossRef]

116. Vrana, J.A.; Gamez, J.D.; Madden, B.J.; Theis, J.D.; Bergen, H.R., 3rd; Dogan, A. Classification of amyloidosis by laser microdissection and mass spectrometry-based proteomic analysis in clinical biopsy specimens. Blood 2009, 114, 4957-4959. [CrossRef] [PubMed]

117. Abe, R.; Katoh, N.; Takahashi, Y.; Takasone, K.; Yoshinaga, T.; Yazaki, M.; Kametani, F.; Sekijima, Y. Distribution of amyloidosis subtypes based on tissue biopsy site-Consecutive analysis of 729 patients at a single amyloidosis center in Japan. Pathol. Int. 2021, 71, 70-79. [CrossRef]

118. Westermark, P.; Benson, M.D.; Buxbaum, J.N.; Cohen, A.S.; Frangione, B.; Ikeda, S.; Masters, C.L.; Merlini, G.; Saraiva, M.J.; Sipe, J.D. Amyloid: Toward terminology clarification. Report from the Nomenclature Committee of the International Society of Amyloidosis. Amyloid 2005, 12, 1-4. [CrossRef] [PubMed]

119. Pinney, J.H.; Lachmann, H.J.; Sattianayagam, P.T.; Gibbs, S.D.; Wechalekar, A.D.; Venner, C.P.; Whelan, C.J.; Gilbertson, J.A.; Rowczenio, D.; Hawkins, P.N.; et al. Renal transplantation in systemic amyloidosis-importance of amyloid fibril type and precursor protein abundance. Am. J. Transplant. 2013, 13, 433-441. [CrossRef]

120. Angel-Korman, A.; Stern, L.; Sarosiek, S.; Sloan, J.M.; Doros, G.; Sanchorawala, V.; Havasi, A. Long-term outcome of kidney transplantation in AL amyloidosis. Kidney Int. 2019, 95, 405-411. [CrossRef]

121. Andeen, N.K.; Yang, H.Y.; Dai, D.F.; MacCoss, M.J.; Smith, K.D. DnaJ Homolog Subfamily B Member 9 Is a Putative Autoantigen in Fibrillary GN. J. Am. Soc. Nephrol. JASN 2018, 29, 231-239. [CrossRef]

122. El Ters, M.; Bobart, S.A.; Cornell, L.D.; Leung, N.; Bentall, A.; Sethi, S.; Fidler, M.; Grande, J.; Hernandez, L.H.; Cosio, F.G.; et al. Recurrence of DNAJB9-Positive Fibrillary Glomerulonephritis After Kidney Transplantation: A Case Series. Am. J. Kidney Dis. 2020, 76, 500-510. [CrossRef] [PubMed]

123. Kim, W.R.; Terrault, N.A.; Pedersen, R.A.; Therneau, T.M.; Edwards, E.; Hindman, A.A.; Brosgart, C.L. Trends in waiting list registration for liver transplantation for viral hepatitis in the United States. Gastroenterology 2009, 137, 1680-1686. [CrossRef]

124. Younossi, Z.M.; Stepanova, M.; Ong, J.; Trimble, G.; AlQahtani, S.; Younossi, I.; Ahmed, A.; Racila, A.; Henry, L. Nonalcoholic Steatohepatitis Is the Most Rapidly Increasing Indication for Liver Transplantation in the United States. Clin. Gastroenterol. Hepatol. 2021, 19, 580-589.e5. [CrossRef] [PubMed]

125. Samuel, D.; Muller, R.; Alexander, G.; Fassati, L.; Ducot, B.; Benhamou, J.P.; Bismuth, H. Liver transplantation in European patients with the hepatitis B surface antigen. N. Engl. J. Med. 1993, 329, 1842-1847. [CrossRef] 
126. Todo, S.; Demetris, A.J.; Van Thiel, D.; Teperman, L.; Fung, J.J.; Starzl, T.E. Orthotopic liver transplantation for patients with hepatitis B virus-related liver disease. Hepatology 1991, 13, 619-626.

127. Mutimer, D.; Pillay, D.; Dragon, E.; Tang, H.; Ahmed, M.; O’Donnell, K.; Shaw, J.; Burroughs, N.; Rand, D.; Cane, P.; et al. High pre-treatment serum hepatitis B virus titre predicts failure of lamivudine prophylaxis and graft re-infection after liver transplantation. J. Hepatol. 1999, 30, 715-721. [CrossRef]

128. Markowitz, J.S.; Martin, P.; Conrad, A.J.; Markmann, J.F.; Seu, P.; Yersiz, H.; Goss, J.A.; Schmidt, P.; Pakrasi, A.; Artinian, L.; et al. Prophylaxis against hepatitis B recurrence following liver transplantation using combination lamivudine and hepatitis B immune globulin. Hepatology 1998, 28, 585-589. [CrossRef]

129. Degertekin, B.; Lok, A.S. What is the optimal regimen for preventing hepatitis B recurrence after liver transplantation? Nat. Clin. Pract. Gastroenterol. Hepatol. 2009, 6, 68-69. [CrossRef] [PubMed]

130. Cotter, T.G.; Paul, S.; Sandıkçı, B.; Couri, T.; Bodzin, A.S.; Little, E.C.; Sundaram, V.; Charlton, M. Improved Graft Survival After Liver Transplantation for Recipients With Hepatitis C Virus in the Direct-Acting Antiviral Era. Liver Transplant. 2019, 25, 598-609. [CrossRef] [PubMed]

131. Bethea, E.; Arvind, A.; Gustafson, J.; Andersson, K.; Pratt, D.; Bhan, I.; Thiim, M.; Corey, K.; Bloom, P.; Markmann, J.; et al. Immediate administration of antiviral therapy after transplantation of hepatitis C-infected livers into uninfected recipients: Implications for therapeutic planning. Am. J. Transplant. 2020, 20, 1619-1628. [CrossRef]

132. Bizollon, T.; Ducerf, C.; Trepo, C.; Mutimer, D. Hepatitis C virus recurrence after liver transplantation. Gut 1999, 44, 575-578. [CrossRef] [PubMed]

133. Teixeira, R.; Pastacaldi, S.; Papatheodoridis, G.V.; Burroughs, A.K. Recurrent hepatitis C after liver transplantation. J. Med. Virol. 2000, 61, 443-454. [CrossRef]

134. Ghobrial, R.M.; Farmer, D.G.; Baquerizo, A.; Colquhoun, S.; Rosen, H.R.; Yersiz, H.; Markmann, J.F.; Drazan, K.E.; Holt, C.; Imagawa, D.; et al. Orthotopic liver transplantation for hepatitis C: Outcome, effect of immunosuppression, and causes of retransplantation during an 8-year single-center experience. Ann. Surg. 1999, 229, 824-831, discussion 831-823. [CrossRef]

135. Verna, E.C.; Abdelmessih, R.; Salomao, M.A.; Lefkowitch, J.; Moreira, R.K.; Brown, R.S., Jr. Cholestatic hepatitis C following liver transplantation: An outcome-based histological definition, clinical predictors, and prognosis. Liver Transplant. Off. Publ. Am. Assoc. Study Liver Dis. Int. Liver Transplant. Soc. 2013, 19, 78-88. [CrossRef]

136. Neumann, U.P.; Berg, T.; Bahra, M.; Seehofer, D.; Langrehr, J.M.; Neuhaus, R.; Radke, C.; Neuhaus, P. Fibrosis progression after liver transplantation in patients with recurrent hepatitis C. J. Hepatol. 2004, 41, 830-836. [CrossRef]

137. Mutimer, D.J.; Gunson, B.; Chen, J.; Berenguer, J.; Neuhaus, P.; Castaing, D.; Garcia-Valdecasas, J.C.; Salizzoni, M.; Moreno, G.E.; Mirza, D. Impact of donor age and year of transplantation on graft and patient survival following liver transplantation for hepatitis C virus. Transplantation 2006, 81, 7-14. [CrossRef]

138. Omata, M.; Yokosuka, O.; Takano, S.; Kato, N.; Hosoda, K.; Imazeki, F.; Tada, M.; Ito, Y.; Ohto, M. Resolution of acute hepatitis C after therapy with natural beta interferon. Lancet 1991, 338, 914-915. [CrossRef]

139. Berg, T.; Hoffmann, R.M.; Teuber, G.; Leifeld, L.; Lafrenz, M.; Baumgarten, R.; Spengler, U.; Zeuzem, S.; Pape, G.R.; Hopf, U. Efficacy of a short-term ribavirin plus interferon alpha combination therapy followed by interferon alpha alone in previously untreated patients with chronic hepatitis C: A randomized multicenter trial. Liver 2000, 20, 427-436. [CrossRef] [PubMed]

140. Carrat, F.; Bani-Sadr, F.; Pol, S.; Rosenthal, E.; Lunel-Fabiani, F.; Benzekri, A.; Morand, P.; Goujard, C.; Pialoux, G.; Piroth, L.; et al. Pegylated interferon alfa- $2 b$ vs standard interferon alfa- $2 b$, plus ribavirin, for chronic hepatitis $C$ in HIV-infected patients: A randomized controlled trial. JAMA 2004, 292, 2839-2848. [CrossRef] [PubMed]

141. Terrault, N.A. Prophylactic and preemptive therapies for hepatitis $C$ virus-infected patients undergoing liver transplantation. Liver Transplant. 2003, 9, S95-S100. [CrossRef]

142. Bzowej, N.; Nelson, D.R.; Terrault, N.A.; Everson, G.T.; Teng, L.L.; Prabhakar, A.; Charlton, M.R. PHOENIX: A randomized controlled trial of peginterferon alfa-2a plus ribavirin as a prophylactic treatment after liver transplantation for hepatitis $C$ virus. Liver Transplant. 2011, 17, 528-538. [CrossRef] [PubMed]

143. Kumada, H.; Toyota, J.; Okanoue, T.; Chayama, K.; Tsubouchi, H.; Hayashi, N. Telaprevir with peginterferon and ribavirin for treatment-naive patients chronically infected with HCV of genotype 1 in Japan. J. Hepatol. 2012, 56, 78-84. [CrossRef] [PubMed]

144. Fried, M.W.; Buti, M.; Dore, G.J.; Flisiak, R.; Ferenci, P.; Jacobson, I.; Marcellin, P.; Manns, M.; Nikitin, I.; Poordad, F.; et al. Oncedaily simeprevir (TMC435) with pegylated interferon and ribavirin in treatment-naïve genotype 1 hepatitis C: The randomized PILLAR study. Hepatology 2013, 58, 1918-1929. [CrossRef] [PubMed]

145. Manns, M.; Pol, S.; Jacobson, I.M.; Marcellin, P.; Gordon, S.C.; Peng, C.Y.; Chang, T.T.; Everson, G.T.; Heo, J.; Gerken, G.; et al. All-oral daclatasvir plus asunaprevir for hepatitis $C$ virus genotype 1b: A multinational, phase 3, multicohort study. Lancet 2014, 384, 1597-1605. [CrossRef]

146. Ikegami, T.; Ueda, Y.; Akamatsu, N.; Ishiyama, K.; Goto, R.; Soyama, A.; Kuramitsu, K.; Honda, M.; Shinoda, M.; Yoshizumi, T.; et al. Asunaprevir and daclatasvir for recurrent hepatitis $\mathrm{C}$ after liver transplantation: A Japanese multicenter experience. Clin. Transplant. 2017, 31, e13109. [CrossRef] [PubMed]

147. Bourlière, M.; Bronowicki, J.P.; de Ledinghen, V.; Hézode, C.; Zoulim, F.; Mathurin, P.; Tran, A.; Larrey, D.G.; Ratziu, V.; Alric, L.; et al. Ledipasvir-sofosbuvir with or without ribavirin to treat patients with HCV genotype 1 infection and cirrhosis non-responsive to previous protease-inhibitor therapy: A randomised, double-blind, phase 2 trial (SIRIUS). Lancet. Infect. Dis. 2015, 15, 397-404. [CrossRef] 
148. Elfeki, M.A.; Abou Mrad, R.; Modaresi Esfeh, J.; Zein, N.N.; Eghtesad, B.; Zervos, X.; Hanouneh, I.A.; O'Shea, R.; Carey, W.D.; Alkhouri, N. Sofosbuvir/Ledipasvir Without Ribavirin Achieved High Sustained Virologic Response for Hepatitis C Recurrence After Liver Transplantation: Two-Center Experience. Transplantation 2017, 101, 996-1000. [CrossRef]

149. Ueda, Y.; Kobayashi, T.; Ikegami, T.; Miuma, S.; Mizuno, S.; Akamatsu, N.; Takaki, A.; Ishigami, M.; Takatsuki, M.; Sugawara, Y.; et al. Efficacy and safety of glecaprevir and pibrentasvir treatment for 8 or 12 weeks in patients with recurrent hepatitis $C$ after liver transplantation: A Japanese multicenter experience. J. Gastroenterol. 2019, 54, 660-666. [CrossRef] [PubMed]

150. Figueras, J.; Jaurrieta, E.; Valls, C.; Benasco, C.; Rafecas, A.; Xiol, X.; Fabregat, J.; Casanovas, T.; Torras, J.; Baliellas, C.; et al. Survival after liver transplantation in cirrhotic patients with and without hepatocellular carcinoma: A comparative study. Hepatology 1997, 25, 1485-1489. [CrossRef]

151. Mazzaferro, V.; Regalia, E.; Doci, R.; Andreola, S.; Pulvirenti, A.; Bozzetti, F.; Montalto, F.; Ammatuna, M.; Morabito, A.; Gennari, L. Liver transplantation for the treatment of small hepatocellular carcinomas in patients with cirrhosis. N. Engl. J. Med. 1996, 334, 693-699. [CrossRef] [PubMed]

152. Yao, F.Y.; Ferrell, L.; Bass, N.M.; Watson, J.J.; Bacchetti, P.; Venook, A.; Ascher, N.L.; Roberts, J.P. Liver transplantation for hepatocellular carcinoma: Expansion of the tumor size limits does not adversely impact survival. Hepatology 2001, 33, 1394-1403. [CrossRef] [PubMed]

153. Kaido, T.; Ogawa, K.; Mori, A.; Fujimoto, Y.; Ito, T.; Tomiyama, K.; Takada, Y.; Uemoto, S. Usefulness of the Kyoto criteria as expanded selection criteria for liver transplantation for hepatocellular carcinoma. Surgery 2013, 154, 1053-1060. [CrossRef]

154. Halazun, K.J.; Rosenblatt, R.E.; Mehta, N.; Lai, Q.; Hajifathalian, K.; Gorgen, A.; Brar, G.; Sasaki, K.; Doyle, M.B.M.; Tabrizian, P.; et al. Dynamic $\alpha$-Fetoprotein Response and Outcomes After Liver Transplant for Hepatocellular Carcinoma. JAMA Surg. 2021, 156, 559-567. [CrossRef] [PubMed]

155. Razumilava, N.; Gores, G.J. Cholangiocarcinoma. Lancet 2014, 383, 2168-2179. [CrossRef]

156. De Vreede, I.; Steers, J.L.; Burch, P.A.; Rosen, C.B.; Gunderson, L.L.; Haddock, M.G.; Burgart, L.; Gores, G.J. Prolonged disease-free survival after orthotopic liver transplantation plus adjuvant chemoirradiation for cholangiocarcinoma. Liver Transplant. 2000, 6, 309-316. [CrossRef] [PubMed]

157. Darwish Murad, S.; Kim, W.R.; Therneau, T.; Gores, G.J.; Rosen, C.B.; Martenson, J.A.; Alberts, S.R.; Heimbach, J.K. Predictors of pretransplant dropout and posttransplant recurrence in patients with perihilar cholangiocarcinoma. Hepatology 2012, 56, 972-981. [CrossRef]

158. Sapisochin, G.; Rodríguez de Lope, C.; Gastaca, M.; Ortiz de Urbina, J.; Suarez, M.A.; Santoyo, J.; Castroagudín, J.F.; Varo, E.; López-Andujar, R.; Palacios, F.; et al. "Very early" intrahepatic cholangiocarcinoma in cirrhotic patients: Should liver transplantation be reconsidered in these patients? Am. J. Transplant. 2014, 14, 660-667. [CrossRef]

159. Jones, D.E. Autoantigens in primary biliary cirrhosis. J. Clin. Pathol. 2000, 53, 813-821. [CrossRef]

160. Chalifoux, S.L.; Konyn, P.G.; Choi, G.; Saab, S. Extrahepatic Manifestations of Primary Biliary Cholangitis. Gut Liver 2017, 11, 771-780. [CrossRef]

161. Nakanuma, Y. Distribution of B lymphocytes in nonsuppurative cholangitis in primary biliary cirrhosis. Hepatology 1993, 18, 570-575. [CrossRef]

162. Corpechot, C.; Carrat, F.; Bahr, A.; Chrétien, Y.; Poupon, R.E.; Poupon, R. The effect of ursodeoxycholic acid therapy on the natural course of primary biliary cirrhosis. Gastroenterology 2005, 128, 297-303. [CrossRef]

163. Adam, R.; Karam, V.; Delvart, V.; O'Grady, J.; Mirza, D.; Klempnauer, J.; Castaing, D.; Neuhaus, P.; Jamieson, N.; Salizzoni, M.; et al. Evolution of indications and results of liver transplantation in Europe. A report from the European Liver Transplant Registry (ELTR). J. Hepatol. 2012, 57, 675-688. [CrossRef] [PubMed]

164. Singal, A.K.; Guturu, P.; Hmoud, B.; Kuo, Y.F.; Salameh, H.; Wiesner, R.H. Evolving frequency and outcomes of liver transplantation based on etiology of liver disease. Transplantation 2013, 95, 755-760. [CrossRef] [PubMed]

165. Kashyap, R.; Safadjou, S.; Chen, R.; Mantry, P.; Sharma, R.; Patil, V.; Maloo, M.; Ryan, C.; Marroquin, C.; Barry, C.; et al. Living donor and deceased donor liver transplantation for autoimmune and cholestatic liver diseases-an analysis of the UNOS database. J. Gastrointest. Surg. 2010, 14, 1362-1369. [CrossRef] [PubMed]

166. Bosch, A.; Dumortier, J.; Maucort-Boulch, D.; Scoazec, J.Y.; Wendum, D.; Conti, F.; Morard, I.; Rubbia-Brandt, L.; Terris, B.; Radenne, S.; et al. Preventive administration of UDCA after liver transplantation for primary biliary cirrhosis is associated with a lower risk of disease recurrence. J. Hepatol. 2015, 63, 1449-1458. [CrossRef] [PubMed]

167. Kogiso, T.; Egawa, H.; Teramukai, S.; Taniai, M.; Hashimoto, E.; Tokushige, K.; Sakisaka, S.; Sakabayashi, S.; Yamamoto, M.; Umeshita, K.; et al. Risk factors for recurrence of primary biliary cholangitis after liver transplantation in female patients: A Japanese multicenter retrospective study. Hepatol. Commun. 2017, 1, 394-405. [CrossRef]

168. Manousou, P.; Arvaniti, V.; Tsochatzis, E.; Isgro, G.; Jones, K.; Shirling, G.; Dhillon, A.P.; O’Beirne, J.; Patch, D.; Burroughs, A.K. Primary biliary cirrhosis after liver transplantation: Influence of immunosuppression and human leukocyte antigen locus disparity. Liver Transplant. 2010, 16, 64-73. [CrossRef] [PubMed]

169. Charatcharoenwitthaya, P.; Pimentel, S.; Talwalkar, J.A.; Enders, F.T.; Lindor, K.D.; Krom, R.A.; Wiesner, R.H. Long-term survival and impact of ursodeoxycholic acid treatment for recurrent primary biliary cirrhosis after liver transplantation. Liver Transplant. 2007, 13, 1236-1245. [CrossRef]

170. Neuberger, J. Recurrent primary biliary cirrhosis. Liver Transplant. 2003, 9, 539-546. [CrossRef] [PubMed] 
171. Egawa, H.; Sakisaka, S.; Teramukai, S.; Sakabayashi, S.; Yamamoto, M.; Umeshita, K.; Uemoto, S. Long-Term Outcomes of Living-Donor Liver Transplantation for Primary Biliary Cirrhosis: A Japanese Multicenter Study. Am. J. Transplant. 2016, 16, 1248-1257. [CrossRef]

172. Li, X.; Peng, J.; Ouyang, R.; Yang, Y.; Yu, C.; Lin, H. Risk factors for recurrent primary biliary cirrhosis after liver transplantation: A systematic review and meta-analysis. Dig. Liver Dis. 2021, 53, 309-317. [CrossRef]

173. Egawa, H.; Nakanuma, Y.; Maehara, Y.; Uemoto, S.; Eguchi, S.; Sato, Y.; Shirabe, K.; Takatsuki, M.; Mori, A.; Yamamoto, M.; et al. Disease recurrence plays a minor role as a cause for retransplantation after living-donor liver transplantation for primary biliary cirrhosis: A multicenter study in Japan. Hepatol. Res. 2013, 43, 502-507. [CrossRef]

174. Chapman, R.; Fevery, J.; Kalloo, A.; Nagorney, D.M.; Boberg, K.M.; Shneider, B.; Gores, G.J. Diagnosis and management of primary sclerosing cholangitis. Hepatology 2010, 51, 660-678. [CrossRef]

175. Burak, K.; Angulo, P.; Pasha, T.M.; Egan, K.; Petz, J.; Lindor, K.D. Incidence and risk factors for cholangiocarcinoma in primary sclerosing cholangitis. Am. J. Gastroenterol. 2004, 99, 523-526. [CrossRef]

176. Boonstra, K.; Weersma, R.K.; van Erpecum, K.J.; Rauws, E.A.; Spanier, B.W.; Poen, A.C.; van Nieuwkerk, K.M.; Drenth, J.P.; Witteman, B.J.; Tuynman, H.A.; et al. Population-based epidemiology, malignancy risk, and outcome of primary sclerosing cholangitis. Hepatology 2013, 58, 2045-2055. [CrossRef]

177. Graziadei, I.W.; Wiesner, R.H.; Marotta, P.J.; Porayko, M.K.; Hay, J.E.; Charlton, M.R.; Poterucha, J.J.; Rosen, C.B.; Gores, G.J.; LaRusso, N.F.; et al. Long-term results of patients undergoing liver transplantation for primary sclerosing cholangitis. Hepatology 1999, 30, 1121-1127. [CrossRef] [PubMed]

178. Hildebrand, T.; Pannicke, N.; Dechene, A.; Gotthardt, D.N.; Kirchner, G.; Reiter, F.P.; Sterneck, M.; Herzer, K.; Lenzen, H.; Rupp, C.; et al. Biliary strictures and recurrence after liver transplantation for primary sclerosing cholangitis: A retrospective multicenter analysis. Liver Transplant. 2016, 22, 42-52. [CrossRef] [PubMed]

179. Alabraba, E.; Nightingale, P.; Gunson, B.; Hubscher, S.; Olliff, S.; Mirza, D.; Neuberger, J. A re-evaluation of the risk factors for the recurrence of primary sclerosing cholangitis in liver allografts. Liver Transplant. 2009, 15, 330-340. [CrossRef] [PubMed]

180. Campsen, J.; Zimmerman, M.A.; Trotter, J.F.; Wachs, M.; Bak, T.; Steinberg, T.; Kam, I. Clinically recurrent primary sclerosing cholangitis following liver transplantation: A time course. Liver Transplant. 2008, 14, 181-185. [CrossRef]

181. Egawa, H.; Ueda, Y.; Ichida, T.; Teramukai, S.; Nakanuma, Y.; Onishi, S.; Tsubouchi, H. Risk factors for recurrence of primary sclerosing cholangitis after living donor liver transplantation in Japanese registry. Am. J. Transplant 2011, 11, 518-527. [CrossRef] [PubMed]

182. Kashyap, R.; Mantry, P.; Sharma, R.; Maloo, M.K.; Safadjou, S.; Qi, Y.; Jain, A.; Maliakkal, B.; Ryan, C.; Orloff, M. Comparative analysis of outcomes in living and deceased donor liver transplants for primary sclerosing cholangitis. J. Gastrointest. Surg. 2009, 13, 1480-1486. [CrossRef]

183. Gordon, F.D.; Goldberg, D.S.; Goodrich, N.P.; Lok, A.S.; Verna, E.C.; Selzner, N.; Stravitz, R.T.; Merion, R.M. Recurrent primary sclerosing cholangitis in the Adult-to-Adult Living Donor Liver Transplantation Cohort Study: Comparison of risk factors between living and deceased donor recipients. Liver Transplant. 2016, 22, 1214-1222. [CrossRef]

184. Dhillon, A.K.; Kummen, M.; Trøseid, M.; Åkra, S.; Liaskou, E.; Moum, B.; Vesterhus, M.; Karlsen, T.H.; Seljeflot, I.; Hov, J.R. Circulating markers of gut barrier function associated with disease severity in primary sclerosing cholangitis. Liver Int. 2019, 39, 371-381. [CrossRef]

185. Martinez, M.; Perito, E.R.; Valentino, P.; Mack, C.L.; Aumar, M.; Broderick, A.; Draijer, L.G.; Fagundes, E.D.T.; Furuya, K.N.; Gupta, N.; et al. Recurrence of Primary Sclerosing Cholangitis after Liver Transplant in Children: An International Observational Study. Hepatology 2021, 74, 2047-2057. [CrossRef] [PubMed]

186. Krawitt, E.L. Autoimmune hepatitis. N. Engl. J. Med. 2006, 354, 54-66. [CrossRef] [PubMed]

187. EASL Clinical Practice Guidelines: Autoimmune hepatitis. J. Hepatol. 2015, 63, 971-1004. [CrossRef]

188. Manns, M.; Gerken, G.; Kyriatsoulis, A.; Staritz, M.; Meyer zum Büschenfelde, K.H. Characterisation of a new subgroup of autoimmune chronic active hepatitis by autoantibodies against a soluble liver antigen. Lancet 1987, 1, 292-294. [CrossRef]

189. Tanaka, A. Autoimmune Hepatitis: 2019 Update. Gut Liver 2020, 14, 430-438. [CrossRef] [PubMed]

190. Czaja, A.J. Rapidity of treatment response and outcome in type 1 autoimmune hepatitis. J. Hepatol. 2009, 51, 161-167. [CrossRef]

191. Wright, H.L.; Bou-Abboud, C.F.; Hassanein, T.; Block, G.D.; Demetris, A.J.; Starzl, T.E.; Van Thiel, D.H. Disease recurrence and rejection following liver transplantation for autoimmune chronic active liver disease. Transplantation 1992, 53, 136-139. [CrossRef] [PubMed]

192. Narumi, S.; Hakamada, K.; Sasaki, M.; Freise, C.E.; Stock, P.G.; Roberts, J.P.; Ascher, N.L. Liver transplantation for autoimmune hepatitis: Rejection and recurrence. Transplant. Proc. 1999, 31, 1955-1956. [CrossRef]

193. Milkiewicz, P.; Hubscher, S.G.; Skiba, G.; Hathaway, M.; Elias, E. Recurrence of autoimmune hepatitis after liver transplantation. Transplantation 1999, 68, 253-256. [CrossRef] [PubMed]

194. Montano-Loza, A.J.; Bhanji, R.A.; Wasilenko, S.; Mason, A.L. Systematic review: Recurrent autoimmune liver diseases after liver transplantation. Aliment. Pharm. 2017, 45, 485-500. [CrossRef] [PubMed]

195. Milkiewicz, P.; Gunson, B.; Saksena, S.; Hathaway, M.; Hubscher, S.G.; Elias, E. Increased incidence of chronic rejection in adult patients transplanted for autoimmune hepatitis: Assessment of risk factors. Transplantation 2000, 70, 477-480. [CrossRef] [PubMed] 
196. McCabe, M.; Rush, N.; Lammert, C.; Patidar, K.R.; Nephew, L.; Saxena, R.; Ekser, B.; Salven, J.; Kubal, C.; Ghabril, M. HLA-DR Mismatch and Black Race Are Associated With Recurrent Autoimmune Hepatitis After Liver Transplantation. Transpl. Direct 2021, 7, e714. [CrossRef]

197. Montano-Loza, A.J.; Mason, A.L.; Ma, M.; Bastiampillai, R.J.; Bain, V.G.; Tandon, P. Risk factors for recurrence of autoimmune hepatitis after liver transplantation. Liver Transplant. 2009, 15, 1254-1261. [CrossRef]

198. Cattan, P.; Berney, T.; Conti, F.; Calmus, Y.; Homberg, J.C.; Houssin, D.; Soubrane, O. Outcome of orthotopic liver transplantation in autoimmune hepatitis according to subtypes. Transpl. Int. 2002, 15, 34-38. [CrossRef]

199. De Quadros Onofrio, F.; Neong, E.; Adebayo, D.; Kollmann, D.; Adeyi, O.A.; Fischer, S.; Hirschfield, G.M.; Hansen, B.E.; Bhat, M.; Galvin, Z.; et al. Single-Center North American Experience of Liver Transplantation in Autoimmune Hepatitis: Infrequent Indication but Good Outcomes for Patients. J. Can. Assoc. Gastroenterol. 2021, 4, 137-144. [CrossRef] [PubMed]

200. Montano-Loza, A.J.; Wasilenko, S.; Bintner, J.; Mason, A.L. Cyclosporine A protects against primary biliary cirrhosis recurrence after liver transplantation. Am. J. Transplant. 2010, 10, 852-858. [CrossRef]

201. Ravikumar, R.; Tsochatzis, E.; Jose, S.; Allison, M.; Athale, A.; Creamer, F.; Gunson, B.; Iyer, V.; Madanur, M.; Manas, D.; et al Risk factors for recurrent primary sclerosing cholangitis after liver transplantation. J. Hepatol. 2015, 63, 1139-1146. [CrossRef] [PubMed]

202. Cholongitas, E.; Shusang, V.; Papatheodoridis, G.V.; Marelli, L.; Manousou, P.; Rolando, N.; Patch, D.; Rolles, K.; Davidson, B.; Burroughs, A.K. Risk factors for recurrence of primary sclerosing cholangitis after liver transplantation. Liver Transplant. 2008, 14, 138-143. [CrossRef]

203. Reich, D.J.; Fiel, I.; Guarrera, J.V.; Emre, S.; Guy, S.R.; Schwartz, M.E.; Miller, C.M.; Sheiner, P.A. Liver transplantation for autoimmune hepatitis. Hepatology 2000, 32, 693-700. [CrossRef] [PubMed]

204. Sørgjerd, E.P. Type 1 Diabetes-related Autoantibodies in Different Forms of Diabetes. Curr. Diabetes Rev. 2019, 15, 199-204. [CrossRef]

205. Bottazzo, G.F.; Florin-Christensen, A.; Doniach, D. Islet-cell antibodies in diabetes mellitus with autoimmune polyendocrine deficiencies. Lancet 1974, 2, 1279-1283. [CrossRef]

206. Månsson, L.; Törn, C.; Landin-Olsson, M. Islet cell antibodies represent autoimmune response against several antigens. Int. J. Exp. Diabetes Res. 2001, 2, 85-90. [CrossRef] [PubMed]

207. Sutherland, D.E.; Goetz, F.C.; Sibley, R.K. Recurrence of disease in pancreas transplants. Diabetes 1989, 38 (Suppl. S1), 85-87. [CrossRef] [PubMed]

208. Sutherland, D.E.; Sibley, R.; Xu, X.Z.; Michael, A.; Srikanta, A.M.; Taub, F.; Najarian, J.; Goetz, F.C. Twin-to-twin pancreas transplantation: Reversal and reenactment of the pathogenesis of type I diabetes. Trans. Assoc. Am. Physicians 1984, 97, 80-87. [PubMed]

209. Vendrame, F.; Hopfner, Y.Y.; Diamantopoulos, S.; Virdi, S.K.; Allende, G.; Snowhite, I.V.; Reijonen, H.K.; Chen, L.; Ruiz, P.; Ciancio, G.; et al. Risk Factors for Type 1 Diabetes Recurrence in Immunosuppressed Recipients of Simultaneous Pancreas-Kidney Transplants. Am. J. Transpl. 2016, 16, 235-245. [CrossRef]

210. Esmatjes, E.; Rodríguez-Villar, C.; Ricart, M.J.; Casamitjana, R.; Martorell, J.; Sabater, L.; Astudillo, E.; Fernández-Cruz, L. Recurrence of immunological markers for type 1 (insulin-dependent) diabetes mellitus in immunosuppressed patients after pancreas transplantation. Transplantation 1998, 66, 128-131. [CrossRef] 